Intraday Market Dynamics Around Public Information Arrivals Angelo Ranaldo

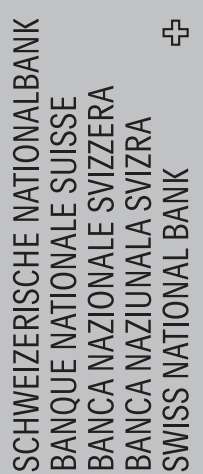


The views expressed in this paper are those of the author(s) and do not necessarily represent those of the Swiss National Bank. Working Papers describe research in progress. Their aim is to elicit comments and to further debate.

ISSN $1660-7716$

๑ 2006 by Swiss National Bank, Börsenstrasse 15, P.0. Box, CH-8022 Zurich 


\title{
Intraday Market Dynamics Around Public Information Arrivals
}

\author{
Angelo Ranaldo* \\ Swiss National Bank \\ Research Department \\ Börsenstrasse 15, P.O. Box 2800 \\ CH-8022 Zurich, Switzerland \\ E-mail: angelo.ranaldo@snb.ch \\ Phone: ++41.44 .6313826$ \\ Fax: ++41.44 .6313901 .
}

\footnotetext{
* I am especially indebted to Joel Hasbrouck who provided me a number of insights when I was a Visiting Scholar at the Stern Department of Finance in 1999. I would also like to thank Bruno Biais, Fabrizio Ferri, Thierry Foucault, James Hamilton, Dušan Isakov, Robert Jennings (AFA discussant), Hung Neng Lai, Alen Vukic and the anonymous referee of the SNB working paper series for their comments. All errors are mine. The views expressed herein are those of the authors and not necessarily those of the Swiss National Bank, which does not accept any responsibility for the contents and opinions expressed in this paper.
} 


\title{
Intraday Market Dynamics Around Public Information Arrivals
}

\begin{abstract}
I analyze the price discovery, liquidity provision, and transaction-cost components driven by the real-time firm-specific news at the Paris Bourse. I find that the news impact depends on which type of news bulletin is released. Only news items causing extreme price disruptions such as earnings announcements enlarge spreads and information asymmetry risk. In contrast, the greater part of real-time firm-specific news releases is a magnet for liquidity and trading. This research provides insights into the market quality of limit-order book markets in which liquidity provision dynamically adapts to market conditions and information events. Limit order traders sustain liquidity even when facing extreme news impacts.
\end{abstract}

Keywords: real-time information; firm-specific news; price discovery; liquidity provision; transaction-cost components; information asymmetry; limit-order book market; earnings announcements; price disruption; high-frequency data

GEL Codes: G10; G14 
How does the real-time release of firm-specific news characterize the order flow and trading activity? Do information releases deteriorate or improve market liquidity? How does a market structure based on voluntary liquidity provision accommodate information events? Do submitters of limit orders demand more compensation to provide liquidity during the price revision process? Are news announcements preceded or followed by information asymmetry? Are extreme price changes driven by news arrivals associated with an illiquid market or with an extraordinary demand for liquidity? I address these fundamental questions in this paper.

A distinguishing characteristic of my study concerns the type and timing of news items. Using the Reuters alert system, I collect six months of firm-specific alerts for 30 highly liquid French stocks. Previous studies focused on specific cases of anticipated information disclosures, such as earnings, dividend, or macroeconomic news announcements. Instead, my research embraces all firm-specific news items that are routed in real-time to the traders' trading screens. The Reuters alerts system has been already used in the previous literature but only partially or with a lower extent of precision. Some studies used it to extract only specific news items (e.g. earnings announcements). Others clustered all news categories together to measure the aggregate market impact (e.g. Berry and Howe, 1994; Mitchell and Mulherin, 1994). Here I examine the entire flow of firm-specific news releases in a finer detail. The benefits of this kind of information flow are twofold. First, it represents the relevant information set that characterizes a trader's decisions. The firm-specific news alert system covers all the pertinent aspects influencing the firm's value, such as its core business, its competitors and sectors, all valuable trading information (e.g. information officially released by the company, interviews, press digest, analysts' research, etc.), and all market and corporate information (e.g. market index compositions, issuance of corporate bonds or new securities, mergers and acquisitions, etc.). Second, firm-specific news alerts represent the actual real-time information flow monitored by traders. The technology implies a continuous monitoring of 
news and order flows. The pervasive presence of day-traders looking for stale orders compels limit-order submitters to update their quotes continuously. The so-called "SOES bandits" at the NASDAQ represent an indicative example ${ }^{1}$. However, short-term trading strategies need to be continuously revised on the basis of the incoming order flow and news arrivals. My research provides insights into the dynamic relations between the real-time news and order flows. Part of the previous literature shows that traders actively monitor and promptly react to the real-time information flow. My research attempts to go one step further by showing the different patterns of the market response.

Considerable effort has so far been devoted to analyzing the market impact of earnings and dividend announcements. I also analyze the minute-by-minute market reaction to real-time earnings announcements. My results are essentially consistent with the previous literature. However, by contrasting the market impact of earnings announcements and other firm-specific news arrivals, two major points emerge. First, the whole information flow, and not just earnings announcements, has a significant market impact. Second, and more importantly, typical realtime firm-specific news and earnings announcements characterize trading in opposing ways. While the latter widens the spread and volatility as widely documented in the literature, the former attracts both liquidity and trading. These results suggest that liquidity providers promptly recognize and efficiently react to the information content of the real-time new release. When the piece of news conveys no major contents, they compete with one another in undercutting and overbidding strategies that result in a thinner spread and larger market depth. When the information release impacts more severely onto prices, a sharp price adjustment demands an immediate execution for greater trading volumes that absorb market liquidity. Even in extreme price disruptions, however, new limit orders fill the book and liquidity supply

\footnotetext{
${ }^{1}$ The NASDAQ's small execution system (SOES) allows brokerage firms to execute small orders automatically at the best quotes. Although this was intended for retail investors, SOES mainly attracted day traders called SOES
} 
remains elevated. Thus, my findings suggest a dynamic adaptation of liquidity provision along with market conditions and the real-time information flow.

Theoretically, a liquid market ensures that trades of any volume size will be executed immediately and without price impact. In practice, if there is uncertainty regarding asset values, market liquidity could collapse. This is an especially relevant issue for market structures without designated market makers who assure liquidity provision to the market. In this respect, the market microstructure of the Paris Bourse represents an insightful subject to study. Although market structures and trading platforms similar to those of the Paris Bourse have been used elsewhere globally, little research has been devoted to understanding how these markets assimilate information events. There are seminal papers that empirically analyze limit order book markets (e.g. Biais, Hillion and Spatt, 1995; Hamao and Hasbrouck, 1995; Ahn, Bae and Chan, 2001; Sandås, 2001; Hollifield, Miller and Sandås, 2004; just to mention few of them). But there is little literature on how electronic limit order book markets respond to information events and, in particular, to extreme price disruptions. My study attempts to fill this gap in two ways: by analyzing the market behavior around the real-time information arrivals; and by examining the resistance of this market structure to news arrivals with an extreme impact. Goldstein and Kavajecz (2004) show that the liquidity drain after the circuit break at the NYSE on October 27, 1997, was mainly due to the limit-order traders' reluctance to provide liquidity. My findings show that even when information disclosures engender extreme price disruptions, limit-order submitters in a pure limit-order book market actively sustain market liquidity. In so doing, this research provides insights into the viability and market quality of limit-order book markets.

How the information is incorporated in the asset prices is a central issue in finance, particularly for the concepts of market efficiency. Market efficiency requires that information 
be publicly available and that prices adjust immediately to market news. My study analyzes the price discovery process and information asymmetry risk around the release of firm-specific news. To do this, I propose a structural model for the estimation of the transaction-cost components that concerns price discreteness and yet is sensitive to the protracted effects of the trade process. This model expands on some of the existing price formation models based on autoregressive process of the order flow, in particular on the model by Madhavan, Richardson, and Roomans (1997). The estimation of transaction-cost components around public information arrivals shows few adverse selection problems and no additional liquidity supplier's compensation. These cost components, however, increase surrounding news disclosures with an extreme impact.

Although there is a large consensus in the literature about a quick price reaction to information arrivals, previous research provides conflicting evidence on the liquidity response. Several papers find that information events tend to deteriorate market liquidity (e.g. Lee, Mucklow, and Ready, 1993), but other studies find that liquidity remains essentially unchanged (e.g. Brooks, 1994; Morse and Ushman, 1983). Others again provide evidence that the market response to information disclosures depends on different aspects, such as the characteristics of the news bulletin and the market structure. The role of public information disclosures is also controversial from a theoretical perspective. Kim and Verrecchia (1994) propose a model in which anticipated public information stimulates informed judgments among traders who process public disclosure into private information. Thus, a public information announcement prompts market makers to increase the bid-ask size and decreases market liquidity at announcement dates. Diamond and Verrecchia (1991), meanwhile, show that public disclosure improves the adverse selection problem. This implies that the market becomes more liquid at the time of a public announcement. To some extent, my study reconciles these opposing views. I find that only information disclosures which imply severe price adjustments, such as earnings 
announcements, reduce market liquidity and, more specifically, enlarge the spread size. In contrast, the greater part of real-time firm-specific news releases in limit-order book markets elicits a higher liquidity provision by narrowing spreads and enlarging market depth.

The paper proceeds as follows: section 1 describes the main features of the market structure of Paris Bourse and the dataset. Section 2 provides a literature survey. Section 3 gives a descriptive analysis of the news impact. Section 4 presents the model for the cost components measurement. Section 5 reports the empirical findings. Section 6 concludes.

\section{Dataset and Market Microstructure}

\subsection{STRUCTURE OF THE PARIS BOURSE}

In 1986, the Paris Bourse introduced a fully automated trading system. After this structural change, the Paris Bourse grew impressively. In 1999, the yearly number of trades was 59 million and the total stock market capitalization was around $€ 723$ billion (Parisbourse, 1999). At the end of 1999, the total market capitalization of the Paris Bourse was slightly higher than the German market, about half that of its London counterpart, and less than an eighth of the NYSE market value.

The market structure of the Paris Bourse is based on a centralized electronic market with the limit-order book publicly visible. The French stock exchange is an order-driven market ${ }^{2}$. Some traders voluntarily offer liquidity by filling the order book with limit orders. To compensate liquidity providers, traders who demand an immediate buy (sell) trade at a relatively higher (lower) price, i.e. the ask (bid) quotes. The difference between bid and ask quotes represents the liquidity provider's gross profit, i.e., their compensation for bearing

\footnotetext{
${ }^{2}$ Designated market makers operate only for less liquid stocks. The market for CAC40 stocks is fully orderdriven.
} 
inventory and adverse selection risks, brokerage commissions, communication costs, clearing, and other factors.

The market opens at 9:00 a.m. and closes at 5:30 p.m. Trading takes place on a continuous basis. Traders may submit limit orders (à cour limité) indicating the highest (lowest) price at which they are willing to buy (sell). Otherwise, traders may immediately transact two types of market orders: an order at the market price (au prix du marché) or at any price (à tout prix). The main principle of the order book is the price-time priority rule.

For highly traded stocks, limit-order traders constantly update the limit-order book (e.g. Bias, Hillion, and Spatt, 1995). The information in the limit-order book is publicly available and disseminated worldwide. In fact, real-time information is routed to more than 500,000 terminals. Of the submitted orders, $44 \%$ come from overseas terminal traders (Parisbourse, 2000). Only institutional agents and investment firms, called trading members, are authorized to submit orders in the Paris Bourse system. Nevertheless, orders can also be gathered by intermediaries - called order collectors - who then transmit such orders to trading members.

The information in the limit-order book is visible on the trading screen for each stock. The information comprises the security symbol; the number of shares traded since the opening; the price changes between the last trade and the previous day's close; the number of shares exchanged and the price and time stamp of the most recent five trades; and the limit price, number of orders, cumulated order size, and time stamp for the five highest bid and five lowest ask quotes.

\section{Table 1 should be inserted here}

\section{B DATABASE}

The database provides time stamp, price, and volumes size of all trades, and time stamp, 
cumulated order size, and price quotes of the prevailing bid and ask quotes. Limit orders other than the best quotes are not considered in this research.

Matching between trade and order data allows me to reconstruct the state of the limit order book before, after, and during the trades. I reconstruct the sequence of the best order changes and trade executions for a six-month period from April to September 1999. This sample period includes 2,592,565 trades and it is a representative period after the introduction of the Euro. One may question if this period is biased by a positive trend (from April to September 1999, the CA40 index increased by 8\%). My sample is not exposed to this criticism. Almost half of the stocks in my sample had a negative performance or their prices remained essentially unchanged.

I analyze 30 highly traded stocks quoted on the Premier Marché, i.e. the market for large French and foreign companies with a market capitalization at least of $€ 750$ million and $25 \%$ of capital publicly available. These 30 stocks are components of the CAC 40 index. For each stock, Table 1 reports the name, market capitalization, price change over the sample period, average daily number of trades, and average daily trading volume. This table shows that the stocks in my sample are extremely liquid. In fact, the average daily number of trades and the daily turnover are similar to the NYSE sample analyzed by Venkataraman (2001).

Table 1 also reports the average values of the time-weighted quoted bid-ask spread. I denote the prevailing ask and the bid quotes at time $t$ as $A_{t}$ and $B_{t} \cdot M_{t}=\left(A_{t}+B_{t}\right) / 2$ is the corresponding midquote price in $\mathrm{t}$, and $\mathrm{QS}_{\mathrm{t}}=\left(\mathrm{A}_{\mathrm{t}}-\mathrm{B}_{\mathrm{t}}\right)$ is the quoted spread. The spread is a rough measure of the gross profit for providing liquidity, or, in other words, the cost of a roundtrip trade. Table 1 shows the difference in the quoted spread across stocks, starting from a minimum of $€ 0.036$ for the Usinor stock to a maximum of $€ 1.219$ for the Promodes stock. The percentage relative spread (PRS) is a standardized measure of the quoted spreads, 
$\mathrm{PRS}_{\mathrm{t}}=\mathrm{QS}_{\mathrm{t}} / \mathrm{M}_{\mathrm{t}}$. The largest and smallest values of the PRS are 0.305 and 0.127 respectively. The spread statistics in my sample are in line with the previous literature ${ }^{3}$.

Table 1 also describes the sample of firm-specific news gathered through the alert system of the Reuters 2000 service. A user can request that the Reuters alert system be notified for eight news categories: all alerts, general, political, market, economic, industrial, corporate, and firm-specific news. In this study, I consider only firm-specific news alerts. Thus, I was able to request notification of firm-specific news for the 30 stocks in my sample and the CAC 40 index. From April to September 1999, I recorded date, time stamp, and news headlines for a total of more than 4,900 firm-specific news releases.

I analyze only news announcements during the trading day. Whenever a news bulletin is reiterated, I consider only the first release. To detect repetitions, I check if news releases have the same headlines. There are two categories of firm-specific news: index-related news and strictly firm-specific news. Since all the 30 stocks in my sample are members of the CAC 40 index, the Reuters alert system also acknowledges index-related news updates as firm-specific information releases. By activating the alert system for the CAC 40 index, I infer when news primarily refers to the French index.

Figure 1 shows that the trading at the Paris Bourse is more intense at the opening, closing, and around the pre-opening and opening of the US future and stock markets, which occur at around 2:30 and 3:30 p.m. Paris time. Figure 2 shows that index-related news releases follow a similar intraday pattern. In fact, much of the index-related information corresponds to a news bulletin of index reactions to earlier events, such as the Paris Bourse or NYSE openings. Berry and Howe (1994) find a similar intraday seasonality looking at an aggregate measure of public information flow. Ederington and Lee (1993) show that scheduled macroeconomic news

\footnotetext{
${ }^{3}$ See e.g., Declerck (2002) and de Jong, Nijman, and Röell (1996) for the Paris Bourse; Bessembinder and Kaufman (1997) for the NYSE.
} 
releases mostly cause the intraday volatility patterns. My findings suggest that after removing index-related news from the firm-specific information flow, this kind of intraday seasonality is less marked. Throughout this paper, I analyze only the market reaction to strictly firm-specific news. This focus is consistent with my main research aim and allows me to avoid the intraday seasonalities that affect index-related news arrivals.

Table 1 shows the number of firm-specific, index-related, and total news releases for each stock. Total releases are 1,031 index-related bulletins and 3,898 firm-specific news items. There is a wide disparity in the number of news releases in the sample. For instance, only 12 releases referred to Legrand, but 677 referred to Elf. Table 1 also shows the exact time stamp of the 30 earnings announcements analyzed later in this study ${ }^{4}$. I decided to study this specific information item for three main reasons: first, it represents the typical information event analyzed in the literature. Second, the comparison between my results and those in the previous literature provides a robustness check. Third, the identification of earnings announcements is relatively objective and precise. The earnings announcements listed in table 1 were singled out by searching the pertinent bulletins among all the Reuters firm-specific news alerts of each company. The earnings announcement selected for analysis is the earliest announcement time.

Table 2 shows a typical intraday bulletin on France Telecom provided by the Reuters alert system. Out of the 11 news releases, 3 refer to index performance; the typical reaction of the French market to the US market opening. Instead, strictly firm-specific news is closely linked to the firm's core business and competitors. In the examples in Table 2, several news releases refer to rumors of mergers and acquisitions between France Telecom's competitors.

\footnotetext{
${ }^{4}$ Earnings announcements are strictly regulated by the "The Autorite des marchés financiers" (AMF), that is the regulatory authority for the French markets. As stated in the AMF (2004), the AMF requires two interim and final publications of the companies' results, the so-called interim and final publications. The former has to be published quarterly and includes at least the turnover. The later is a yearly bulletin that comprehends all the accounting results. Both are disclosed within the four months after the end of the accounting period and these dates are largely
} 
Table 2 should be inserted here

\section{Literature Review}

\subsection{EMPIRICAL LITERATURE}

Given that the research area related to this study is very wide-ranging, this survey does not pretend to be exhaustive ${ }^{5}$. Although most of the previous literature indicates an immediate price reaction to information arrivals, there is a weak consensus about how market liquidity reacts to news announcements. Hence, in reviewing the literature, I focus my attention on two central questions: (1) whether a news announcement decreases market liquidity (i.e. larger spreads), and (2) the timing of the market reaction.

Dann, Mayers, and Raab (1977), Patell and Wolfson (1984) and Jennings and Starks (1985) were among the first researchers to explore the markets' reaction to new information using intraday data. They investigate whether the market is able to adjust in a timely manner. In general, they find that equity prices react within 15 minutes.

The event study literature has mainly focused on earnings or dividend announcements. Morse and Ushman (1983) find no impact on the closing bid-ask spread size. Lee (1992) shows that in the pre-announcement period there is little evidence of abnormal volume and information leakage. Most of the announcement effect is absorbed in the half hour after the news release and this is manly driven by large trades. Lee, Mucklow, and Ready (1993) find a joint deterioration of spread and market depth in anticipation of earnings announcements. Spreads and quoted depths return to non-announcement levels after three hours. Greene and Watts (1996) find that diverse market structures (e.g. specialist versus dealer markets)

known in advance by traders.

${ }^{5}$ In particular, I will not survey the previous research on macroeconomic news announcements. 
characterize the price discovery process differently. Graham, Koski, and Loewenstein (2003) compare the market impact of anticipated and unanticipated dividend announcements. They find larger volume, volatility and lower liquidity (larger spreads and thinner depth) before anticipated announcements. Afterward, trading volume remains high, but liquidity returns to its normal level. Prior to the unanticipated announcements, they find abnormal volume, but normal liquidity. Next, liquidity deteriorates for a short period. Adverse selection costs preceding the announcements are high, especially for the unexpected releases.

Brooks, Patel, and Su (2003) and Goldstein and Kavajecz (2004) study some special cases of extreme price reactions. Brooks et al. (2003) find that the market needs more time to assimilate extreme information events such as plane crashes and plant explosions. Goldstein and Kavajecz (2004) analyze the liquidity provision around the NYSE halt in trading on October 27, 1997. They find that limit-order traders remain inactive (wider order book spread and a diminished depth) and that liquidity is provided by the specialists.

Another area of the literature focuses specifically on the estimation of the transactioncost components surrounding public information disclosures ${ }^{6}$. Venkatesh and Chiang (1986) find no evidence of information asymmetry ${ }^{7}$. Brooks (1994) finds that spreads appear significantly larger before earnings announcements only for medium-size firms. Krinsky and Lee (1996) show higher (lower) adverse selection costs (inventory holding and order processing costs) for the two days before and after earnings announcements. Affleck-Graves et al. (2002) find that an increase in adverse selection costs on the day prior to earnings announcements affect only NASDAQ firms with less predictable earnings. Jennings (1994) shows little evidence of informed trading before the takeover proposals announcement.

\footnotetext{
${ }^{6}$ Daley, Hughes and Rayburn (1995) infer the adverse selection problem by estimating the permanent price impact and not the cost components. They show that block trades prior to earnings announcements convey more information, especially for small firms.

${ }^{7}$ Venkatesh and Chiang (1986) find some information asymmetry only in the special case when two successive
} 


\subsection{THEORETICAL LITERATURE}

This survey of theoretical models is very broad. I will only refer to few influential papers and expressly omit many other important contributions. The traditional view of asymmetric information models implies a decreasing effect of information asymmetry after new releases ${ }^{8}$. These models imply that liquidity provision deteriorates (widen spread and lower depth) prior to scheduled news announcements. In case of unanticipated announcements, uninformed traders should provide normal liquidity to the market unless they detect information-motivated traders. After the announcement, liquidity should return to normal soon after the new information is processed by the market. Price volatility is associated with the revisions of investors' beliefs. It should remain high only for the duration of the adjustment process. Trading volume can be lower prior to information releases since discretionary liquidity traders may be hesitant to trade. Afterward, volume increases momentarily along with the pent-up demand and portfolio rebalancing.

There are more recent works dedicated to limit-order book markets. A common attribute of these models is a dynamic view of liquidity provision that adapts to market conditions. In Foucault, Kadan, and Kandel (2005), patient traders dynamically respond to the conditions of the order book. They show that undercutting and overbidding strategies are attractive if the competition among limit-order traders is high. Handa, Schwartz and Tiwari (2003) show that the heterogeneity in traders' opinion leads the process of price discovery and liquidity provision. Goettler, Parlour and Rajan (2005) analyze the equilibrium in a dynamic limit order book market in which rational liquidity traders choose optimal submission strategies. Obizhaeva and Wang (2005) develop a model for limit order book markets capturing the

earnings announcements are released within a few days of each other.

\footnotetext{
${ }^{8}$ Two representative works are Glosten and Milgrom (1985) and Easley and O'Hara (1992).
} 
dynamic nature of the liquidity supply and demand when the times of trade is endogenized and determined optimally.

\section{Order Flow Around News Arrivals}

The procedure to analyze the trading activity around the arrival of public news releases is divided into two steps. First, I perform my analysis on firm-by-firm basis. Each firm's average value is then weighted equally in the sample mean. Thus, I calculate the average value of a given trading dimension for each firm. I then calculate the cross-sectional average of this trading dimension across all the firms in my sample. Hence, no pooled average is used. This prevents me from any bias towards more liquid firms or firms with a larger number of information releases.

I decompose the trading time around the exact moment of the news arrivals into 10minute intervals. A distinguishing feature of this decomposition method is that I split the pre and post-announcement periods exactly at the event time (for a similar approach see Graham et al., 2003). A time frame shorter than 10 minutes would presumably provide more precision in identifying the timing of the news impact. On the other hand, a longer time period allows me to minimize the influence of non-information effects, such as the bid-ask bounce. A 10-minute period represents a suitable compromise for this trade-off 9 .

For the trading activity, I calculate price changes, return volatility, trading volume, and intratrade time duration. Price changes are the logarithmic transaction price differences over 10-minute intervals ${ }^{10}$. I calculate realized return volatility by using the Ahn, Bae, and Chan

\footnotetext{
${ }^{9}$ I tested other lengths of time intervals, in particular 5 or 15 minutes. The results remain essentially the same.

${ }^{10}$ One of the purposes of this research is to consider price discreteness. Consistently, I rather analyze transaction prices instead of mid-quote prices. However, using the mid-quote price, statistics and results remain essentially unchanged.
} 
(2001) method, which squares the log price changes and sums up the square returns over the intraday intervals ${ }^{11}$. Trading volume is the average number of shares exchanged in each 10 minute period. The intratrade duration is the average time that elapses between the successive transactions over 10-minute periods.

The order flow values are the order data in the book before the occurrence of any trade. Using the order data, I calculate the quoted bid-ask spread, market depth, and probability of trade continuation. As before, I perform a firm-by-firm analysis and then I average these measures across firms. I measure the spread as the difference between the prevailing ask and bid quotes. As in Lee et al. (1993), market depth is the sum of volumes pending at the best ask and bid quotes. I calculate the probability of trade continuation by using the frequency of two subsequent trades in the same direction, i.e. two successive buys or sells.

The time window to analyze the announcement impact is composed of three 10-minute intervals before, and six 10-minute periods after the news release arrivals. I also considered larger periods of news impact. However, the 90-minute time window represents the appropriate length of time to account for the major intraday news impact. In the same spirit of Lee et al. (1993), the measures of news impact are expressed as a percentage deviation from the nonevent period average for the same firm and time of day. These standardized measures allow for comparisons across firms with their "normal" values. This method also provides a straightforward adjustment for intraday seasonalities. The test for comparing significant differences between announcement and non-announcement periods is based on the t-statistic. ${ }^{12}$

\section{Table 3 should be inserted here}

\footnotetext{
${ }^{11}$ The use of the mid-quote price to calculate realized volatility conducts to the same results.

${ }^{12}$ Additional tests using the Wilcoxson-Mann-Whitney method confirm the results presented in this paper.
} 


\subsection{EARNINGS ANNOUNCEMENTS VERSUS FIRM-SPECIFIC NEWS}

The first question I address is if the market reacts differently to real-time firm-specific news and earnings announcements. By comparing Panels A and B in Table 3, three main results emerge. First, earnings announcements have a larger market impact. This impact results in larger price changes, volatility, trading volume (in size and number of trades). This finding suggests that earnings announcements convey more information than the average real-time news item. Second, earnings announcements have a more persistent effect. An explanation could be that an earnings announcement includes a broad information set that typically implies a time-consuming analysis ${ }^{13}$. Third, market liquidity deteriorates around earnings announcements, i.e. the spread is larger and depth is thinner. Conversely, the arrival of a typical firm-specific news release is associated with a tight spread and normal or larger depth. This interesting result deserves further discussion.

A larger spread around earnings announcements is consistent with the previous empirical literature $^{14}$ and theoretical models linking public information releases with asymmetric information risk (e.g. Kim and Verrecchia, $1994^{15}$; and the class of asymmetric information models discussed above). Instead, a tighter spread around real-time news arrivals may appear at odds with that literature. But there are at least three arguments supporting a possible increase in liquidity in response to information releases. First, the adverse selection problem goes hand in hand with the information content of the news bulletin. Earnings announcements typically convey a more informative communication that lends itself to a higher information asymmetry risk. In this respect, arguments of the traditional asymmetric information models hold. On the

\footnotetext{
${ }^{13}$ All the Reuters' earnings announcements enclose tables about accounting information (balance sheet, income and cash flows statements, etc.).

${ }^{14}$ See e.g. Gajewski (1999) finds larger spreads after earnings announcements at the Paris Bourse.

${ }^{15}$ In Kim and Verrecchia (1994), there is an essential distinction between adverse selection before and after the event as a result of different processing of the announcement.
} 
other hand, the typical real-time news delivers a lower information content and little adverse selection.

Second, the liquidity improvement around some news announcements can be due to a high level of competition among liquidity providers. This argument calls to mind the recent theoretical models discussed above. The competitive pressure in Foucault, Kadan, and Kandel (2005) implies small spreads and a fast mean reversion of the spread towards its normal size. The findings in Panel A of table 3 largely support this view. In the spirit of Handa, Schwartz and Tiwari (2003), earnings announcements that contain large information contents trigger a well-defined price adjustment, larger spreads and volatility. In contrast, regular real-time alerts do not cause a marked divergence of opinion. This implies a weaker price reaction along with in an improvement of market liquidity. Goettler, Parlour and Rajan (2005) shows that volatility (on the true asset value) encourages competition among limit order submitters, regardless of whether they risk to being picked off by informed traders. This leads to more aggressive limit order submission and lower transaction costs.

Finally, most of the existing literature examines particular information disclosures that typically have a large price impact, e.g. earnings announcements (e.g. Lee et al., 1993), macroeconomic news announcements (e.g. Greene, $2004^{16}$ ) or completely unanticipated events (e.g. Brooks et al., 2003). In this paper, I analyze a wider definition of firm-specific news that is disseminated in real-time and displayed on traders' screens in order to attract their attention. Foucault, Roell, and Sandås (2003) feature two important aspects in their model. First, costly monitoring motivates liquidity providers to constantly monitor the information flow and update quotes immediately. Second, costly monitoring coupled with competitive pressure among liquidity providers forces dealers to quote narrower bid-ask spreads and to quickly update their

\footnotetext{
${ }^{16}$ Greene (2004) represents an important antecedent to this paper. He also measures the cost components on the basis of Madhavan et al. (1997) but he studies the macroeconomics news impact on the bond market.
} 
quote. They show that these incentives strengthen when limit-order traders anticipate information events.

\subsection{PRICE DYNAMICS}

A relevant question is whether information disclosures have a significant price impact. Table 3 shows that earnings announcements originate a significant price impact at least 40 minutes after the news release. The price impact is observable in terms of absolute price change and return volatility. Excluding earnings announcements from the entire flow of real-time firm-specific news, there is evidence of price impact only in terms of return volatility rather than absolute price change. In Kim and Verrecchia (1994), the variance of price change increases with the diversity among information processors and with the number of liquidity traders, and it decreases with the precision of the public information and the processing information cost. From this perspective, the increase in volatility after the news arrival may suggest a moderate precision of the public information and that traders need time to interpret the information contents.

It is worth emphasizing that significant price movements are already observable 10 minutes before the Reuters' earnings announcements ${ }^{17}$. There are two possible explanations for this. First, there are many information sources and channels ${ }^{18}$; Reuters is only one of them. Reuters might not be the first information provider to release a given news item. Hence, at the time of Reuters' announcement, the information might already be partially known by the market participants. Second, some traders either trade on rumors or are better informed than

\footnotetext{
${ }^{17}$ This premature market reaction is still observable when slightly different time windows are considered, e.g. delaying the release time by 30 seconds.

${ }^{18}$ Other information sources are television, telephones, emails or direct competitors of Reuters (e.g. Bloomberg or Telekurs). See e.g. the original study of Busse and Green (2002) on stock price reaction to television financial news reports broadcasted by the CNBC channel.
} 
others. The evidence of price movements before the news arrival time suggests that traders have heterogeneous information sets. Ederington and Lee (1995) argue that the complete information of a news announcement only reaches the market gradually. Complete information in a report may not be available immediately. These arguments may explain a protracted process of price adjustment.

\subsection{TRADING VOLUME}

The demand for immediate execution increases around public information arrivals. I observe this evidence both in terms of the number of trades and trading volume size. Consistent with the previous literature (e.g. Graham et al., 2003; Krinsky and Lee, 1996), intense trading lasts around 30-40 minutes for earnings announcements. This length of time suggests that market participants need longer to rebalance their portfolio, satisfy their pent-up demand or adjust their hedging positions.

Table 3 shows that the intratrade duration shortens, suggesting that traders expect less time needed to execute. A significantly faster trading is already observable 10 minutes before earnings announcements and it lasts for 40 minutes afterwards. A similar pattern holds for trading volume. These results are consistent with the empirical evidence on the US stock markets (e.g. Lee, 1992).

Table 3 also shows that the autocorrelation of the trade direction increases around public information arrivals, especially for earnings announcements. Patell and Wolfson (1984) find a similar result. These findings support the argument in Bias, Hillion, and Spatt (1995), who argue that traders react similarly, but successively, to the same events. Higher trade continuation is another signal that the price adjustment follows an ongoing revision process. 


\subsection{EXTREME PRICE CHANGES}

In this part of my study, I examine if and how a limit-order book market is able to support extreme news. To do this, I focus only on those information arrivals that give rise to extreme price changes. I rank news arrivals by the size of the price change from 10 minutes before the news release up to the time of news release as reported by the Returns alert system ${ }^{19}$. I then divide the price changes distribution into 20 equal, ordered subgroups, i.e. 20 quantiles or vintiles. Each vintile is composed of 194 news arrivals. The first (last) vintile represents the lowest (highest) price adjustments to information arrivals. Heuristically, I can interpret the news bulletins related to the first (last) vintile as the worst (best) firm-specific news items released during the sample period. Of course, the realized price impact cannot be used to know a priori whether the piece of news is economically relevant. It can only be used as an ex post measure to infer if the news item was unanticipated.

As in Table 3, Tables 4 and 5 report the cross-sectional average values of the following trading dimensions: price change size, return volatility, trading volume, market depth, intratrade waiting time, quoted spread, frequency of buys and probability of trade continuation. Since the sign of the price change is considered in Tables 4 and 5, the following trading dimensions are also analyzed: the logarithmic change from the best ask (bid) quote to the best ask (bid) quote 10 minutes after (in other terms, the ask-to-ask and bid-to-bid quote changes over the 10-minute intervals), and average values of the cumulated orders pending on the prevailing ask and bid quotes (market depth at the sell and buy side of the order book). As before, the measures of news impact are expressed as a percentage deviation from the nonevent period average for the same firm and time of day. The only exceptions are represented by the measures of price impact. For the sake of clarity, price changes, bid-to-bid, and ask-to-ask

\footnotetext{
${ }^{19}$ I also analyzed an alternative method. I ranked news impacts by ranking price changes from the time of the news arrival to 10 minutes afterwards. This alternative leads to essentially the same results. The main advantage of
} 
quotes changes are expressed as the difference between announcement and non-announcement values in basis points.

Table 4 shows the market dynamics conditional on the price impact of real-time news arrivals. The size of price changes indicates that price movements in the first and last vintile represent considerable price disruptions, i.e. around 40 basis points over a 10-minute period of time $^{20}$. The main findings in Table 4 are that the size of the price change at the time of a news arrival increases with the return volatility, trade frequency, trading volume, bid-ask spread size, and ask-to-ask and bid-to-bid quote changes. Price drops (jumps) are associated with larger bidto-bid (ask-to-ask) quote changes, and with a higher proportion of sells (buys). As in Graham et al. (2003) and Jennings (1994), less clear patterns link price changes with quoted depth. Market depth seems to be thicker when the market is calm or extremely turbulent, i.e. when price changes are relatively moderate (from the $5^{\text {th }}$ to the $15^{\text {th }}$ vintile) and when price fluctuations are extreme $\left(1^{\text {st }}-2^{\text {nd }}\right.$ and $19^{\text {th }}-20^{\text {th }}$ vintiles $)$. One may question if these extreme price disruptions are real news effects or just price move effects. To verify this, I construct a control sample for the same firm and time of day but over non-event days. I randomly pick these returns and then sort them by price change size (in vintiles). This additional test (not tabulated) shows that newsdriven returns are markedly different from systematic price moves.

\section{Table 4 should be inserted here}

Table 5 analyzes the first and last vintiles of the price changes distribution reported in Table 4 in more detail. Table 5 gives additional information on the history of these extreme movements, in particular the market dynamics during the 90-minute time window around news releases. It is worth emphasizing that there is no price adjustment before news releases causing severe price changes. This price stability suggests that, although the release time of these news

the method I use in this study is that it captures the initial impact of the news arrival.

${ }^{20}$ No trading halts occurred during the sample period. 
bulletins may be anticipated, their information contents are essentially unexpected.

Table 5 shows that volatility during extreme price changes is more than $100 \%$ the normal level. Volatility is higher before news releases and tends to decrease afterwards, even if it remains high. As in Brooks et al. (2003), a persistently high level of volatility suggests that the market needs more time to absorb extreme news. As observed for earnings announcements, there is a positive relation between price volatility and spread size. This further supports the idea that only announcements containing important information increase both volatility and spreads.

\section{Table 5 should be inserted here}

It is noteworthy that a greater demand for liquidity, rather than a weak liquidity supply, is associated with extreme price changes. The large number of trades executed and shares exchanged within a very short time supports this assertion. I also note that large trading volume consumes liquidity already 30 minutes before the news release. On the other hand, market depth on both sides of the order book remains in line with its normal value. This evidence suggests that liquidity provision is sufficient if regarded in absolute terms, but insufficient relative to an abnormal, transient liquidity demand. Put differently, extreme price changes are not due to a deficient provision of market liquidity and, therefore, they cannot be considered endogenous.

I gain insights from the short-term dynamics of the bid and ask quotes. The spread size is more than 30\% larger than normal when the market experienced the largest price movements. The dynamics of the bid and ask quote changes show that the spread enlargement is not due to stale orders pending on one side of the order book. In fact, both sides are actively updated and consistently follow the direction of the price adjustment. However, during a steep price increase (decrease), the ask (bid) quote increases (decreases) more than bid (ask) quote. Therefore, 
extreme price movements depend mainly on the elevated trading aggressiveness of one side of the book, and not on the traders' reluctance to provide liquidity on the opposite side of the book. The thickness of the buy and sell sides seems to support this assertion. In fact, price jumps (drops) are associated with a normal or even thicker sell side (buy side) of the book. This evidence is consistent with Parlour (1998) who shows that in a competitive environment, liquidity supply provides higher market depth to the most aggressive side of market.

The final indication in Table 5 is that there is a small price rebound after a price disruption. One could expect a large positive (negative) price rebound after a price drop (jump) because of a large bid-ask spread. On the contrary, Table 5 shows that the reverse price movement is rather small. This is another sign of high liquidity provision by limit-order submitters who promptly fill a wide bid-ask spread.

\section{Price Formation Models and Cost Components Estimation}

The second main objective of my research is to estimate the transaction-cost components surrounding the public information arrivals. To do this, I use an autoregressive model (hereafter AR model) for modeling the price formation behavior. The AR model is a generalization of the Madhavan, Richardson, and Roomans (1997) model (hereafter MRR model). The main features of the MRR model are that the change in the true value of an asset from $t-1$ to $t$ can be due to a non-trading event, such as the arrival of new public information, or a trading event, such as an innovation in the order flow. The arrival of new public information is associated with a public news announcement represented by the i.i.d. innovation $\mathrm{u}_{\mathrm{t}}$. For a trading event, the revision is due to the unexpected order flow. The true value changes in proportion to the deviation between expected order flow, $\mathrm{E}\left[\mathrm{x}_{\mathrm{t}} \mid \mathrm{x}_{\mathrm{t}-1}\right]$, and the actual order flow, $\mathrm{x}_{\mathrm{t}}$. I call this proportion $\theta$. It represents the degree of information asymmetry or the permanent impact of the order flow 
innovation. Hence, the true value process can be expressed as:

$$
\mu_{t}=\mu_{t-1}+\theta\left(x_{t}-E\left[x_{t} \mid x_{t-1}\right]\right)+u_{t}
$$

The second main assumption in the MRR model is that the transaction price, $p_{t}$, corresponds to the efficient price plus a component that impounds various microstructure effects:

$$
\mathrm{p}_{\mathrm{t}}=\mu_{\mathrm{t}}+\phi\left(\mathrm{x}_{\mathrm{t}}\right)+\varepsilon_{\mathrm{t}}
$$

$\phi$ represents compensation for providing liquidity and includes any order processing costs. $\phi$ can be interpreted as the liquidity provider's compensation for inventory risk and for any order processing costs, such as clearing or brokerage fees. Also, $\varepsilon_{t}$ denotes the i.i.d. residual term with mean zero that embodies the effect of stochastic rounding and errors induced by price discreteness. The residual terms in equations (1) and (2) are uncorrelated.

The third main assumption in the MRR model is that the order flow follows a general Markov Chain process characterized by only a one-lag autocorrelation in the order flow. To illustrate this point, let us assume that a sell occurs at time $t$, and thus the transaction price is at the bid. The probability of order persistence, i.e. two subsequent buys or sells, is equal to $\delta$ and the probability of reversal order is $1-\delta$. In this example, the probability that the trade in $t+1$ occurs at the ask and at the bid is $1-\delta$ and $\delta$. Let $\lambda$ represent the unconditional probability that the transaction price occurs within the spread, i.e., $\operatorname{Pr}\left(\mathrm{x}_{\mathrm{t}}=0\right)$. I can then express the order flow in a transition matrix $\mathrm{P}$ as follows:

$$
\mathrm{P}=\left[\begin{array}{c}
-1 \\
0 \\
+1
\end{array}\right]\left[\begin{array}{ccc}
-1 & 0 & +1 \\
(1-\lambda) / 2 & \lambda & 1-\delta-\lambda \\
1-\delta-\lambda & \lambda & \delta
\end{array}\right]
$$

Appendix 1 shows the property of the transition matrix P. I denote $\rho=(2 \delta-(1-\lambda))$. The 
conditional expectation of the trade direction at time $t+1$, given the trade direction in $t$, is:

$$
E\left[x_{t+1} \mid x_{t}\right]=\rho\left(x_{t}\right)
$$

Combining equations (1) and (2) with (4), the main estimation equation of the MRR model is:

$$
\Delta \mathrm{p}_{\mathrm{t}}=(\phi+\theta) \mathrm{x}_{\mathrm{t}}-(\phi+\theta \rho) \mathrm{x}_{\mathrm{t}-1}+\xi_{\mathrm{t}}
$$

where $\xi_{\mathrm{t}}=\mathrm{u}_{\mathrm{t}}+\varepsilon_{\mathrm{t}}-\varepsilon_{\mathrm{t}-1}$ clusters all the residual terms of the true prices and the transaction prices.

The crucial point in the MRR model is to assume only a one-lag autocorrelation in the order flow. Hasbrouck (1991) presents empirical evidence on lasting price and order dynamics. After comparing different models of transaction-cost components, de Jong, Nijman, and Röell (1996) conclude that a one-period empirical implementation underestimates the price effects of trading. Thus, I assume that the order flow follows a more general autoregressive process. Equation (4) can be generalized as follows:

$$
E\left[x_{t+k} \mid x_{t}, x_{t-1}, x_{t-2}, \ldots\right]=\rho^{k} x_{t}
$$

See Appendix 1 for more details. Relaxing the MRR assumption that $\mathrm{k}$ is equal to 1 , the true price process in equation (1) becomes:

$$
\mu_{t}=\mu_{t-1}+\theta\left(x_{t}-\sum_{k} \rho^{k} x_{t-k}\right)+u_{t}
$$

To find a straightforward representation of the estimation equation, I limit the autoregressive decaying impact of the order flow to two lags. This assumption is consistent with the finding in the empirical literature that the significant level in the autoregressive process of the trade indicator series achieves two or, at maximum, three lags. Equation (5) of the MRR model becomes: 


$$
\Delta \mathrm{p}_{\mathrm{t}}=\alpha+(\phi+\theta) \mathrm{x}_{\mathrm{t}}-(\phi+\theta \rho) \mathrm{x}_{\mathrm{t}-1}-\rho^{2} \theta \mathrm{x}_{\mathrm{t}-2}+\xi_{\mathrm{t}}
$$

As before, $\xi_{\mathrm{t}}=\mathrm{u}_{\mathrm{t}}+\zeta_{\mathrm{t}}-\zeta_{\mathrm{t}-1}$ clusters all the residual terms of the true price and the transaction price. The constant $\alpha$ represents the expected change in the asset value.

The AR representation makes the price formation process more robust for the many microstructure imperfections that engender lagged effects. In fact, the literature provides evidence on price discreteness effects (e.g. Harris, 1994), inventory consequences (e.g. Stoll, 1989), lasting adjustments to information (e.g. Patell and Wolfson, 1984), and other strategic behavioral effects, such as order-splitting strategy that induces dilutions in the price impacts or price smoothing effects.

I estimate the AR model by applying the Ordered Probit technique ${ }^{21}$. As in Hausman, Lo, and MacKinlay (1992), I divide the price change sizes into nine categories: when the price drops (jumps) four ticks or less (more), goes down (up) three ticks, down (up) two ticks, down (up) one tick, and, finally, when the price remains unchanged.

Let $\Delta \widetilde{\mathrm{p}}_{\mathrm{t}}$ be the unobservable continuous variable denoting the price changes from t-1 to t. The partition of the state space allows for mapping price changes in $n$ discrete values. Hence, $\Delta \mathrm{p}_{\mathrm{t}}$ is the discrete dependent variable representing the observable price change value. Consistent with equation (8), let $\alpha$ be the constant and $\beta_{i}$ for $i=1,2,3$ be the coefficients related to the regressors $x_{t}, x_{t-1}$ and $x_{t-2}$. The expression of the Ordered Probit regression is as follows:

$$
\Delta \widetilde{\mathrm{p}}_{\mathrm{t}}=\alpha+\beta_{1} \mathrm{x}_{\mathrm{t}}+\beta_{2} \mathrm{x}_{\mathrm{t}-1}+\beta_{3} \mathrm{x}_{\mathrm{t}-2}+\xi_{\mathrm{t}}
$$

\footnotetext{
${ }^{21}$ See Hausman, Lo and MacKinlay (1992) for a more exhaustive discussion about the advantages of using the Ordered Probit approach to treat price discreteness.
} 


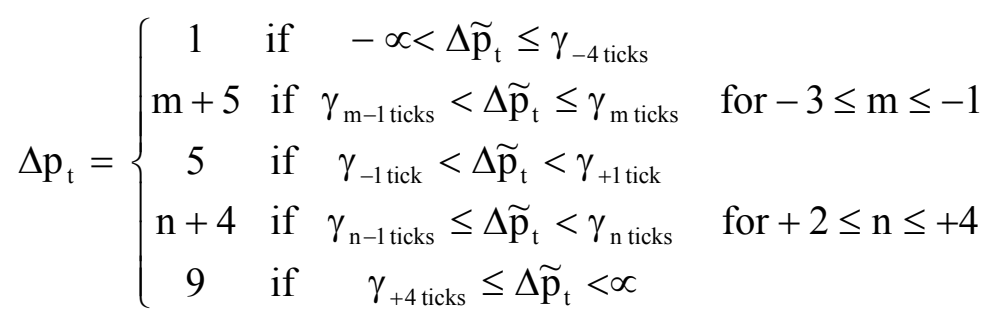

Equation (9) refers to the Probit regression in which $\xi_{t}$ is the independent and nonidentically distributed residual by characteristics of the Probit regression. To take heteroskedasticity into account, I use the Huber/White/sandwich robust method of calculating the variance-covariance matrix. Expression (10) shows the state-space partition and $\gamma_{-4 \text { ticks }}$ to $\gamma_{+4 \text { ticks }}$ are the related thresholds that set the price change sizes in ticks. Assuming Gaussian residuals $\xi_{t}$, one can easily obtain the conditional distribution of $\Delta \widetilde{\mathrm{p}}_{\mathrm{t}}$.

The Probit analysis is performed on a firm-by-firm basis. Therefore, results in Tables 6 and 7 are averaged values across the 30 regressions. Table 6 shows the main statistics of the Ordered Probit regression and confirms the statistical significance of all the explanatory variables but the constant. Hence, both the first and second lags in the order flow are relevant in the price formation process. The Chi-squared statistics in Panel B of Table 6 provides a test for the likelihood ratio about the restrictions that the cost components are the same before and after the news arrivals. These statistics suggest that the cost components are essentially the same before and after any news release. In contrast, the transaction-cost components differ significantly before and after news arrivals that cause extreme price changes. The related Pvalue for the likelihood ratio test is $0.001(0.032)$ when news announcements cause price drops (jumps). In the following section, these findings will be discussed further.

Table 6 should be inserted here 


\section{Empirical Findings on Transaction-Cost Components}

\subsection{TRANSACTION-COST COMPONENTS IN THE PARIS BOURSE}

The estimates in Panel A of Table 7 show the existence of adverse selection cost, order processing cost, and order persistence in limit-order book markets. The order processing cost is the largest cost component. Adverse selection and order persistence components are smaller, but significant.

\section{Table 7 should be inserted here}

Table 7 shows that the average estimates that I derive from the AR model of the adverse selection cost, order processing, and order persistence are $0.41,0.56$, and 0.25 respectively. The monetary values of the cost components are $€ 0.066, € 0.090$, and $€ 0.039$ respectively. To obtain the average monetary values (in $€$ ), I calculate the proportion of the cost components with respect to the quoted spread. The AR model provides estimates of transaction-cost components consistent with the previous literature on the NYSE and other international markets. ${ }^{22}$

\subsection{TRANSACTION-COST COMPONENTS AND NEWS ARRIVALS}

The estimation of the cost components around public information arrivals provides me with straightforward proxies of transaction-cost components over those intraday periods that are characterized by uncertainty on the asset values. Panel B in Table 7 shows the estimates of the cost components conditional on information events. Using piecewise dummy variables, I estimate the transaction-cost components in the two 30-minute time intervals before and after the public information arrivals. Equation (9) is transformed as follows:

\footnotetext{
${ }^{22}$ For the NYSE, see Stoll (1989) and Huang and Stoll (1997); for the Paris Bourse, see Declerck (2002) and de Jong, Nijman, and Röell (1996); for similar results on other limit-order book markets, see e.g. Brockman and Chung (1999) for the Hong Kong Stock Exchange, and Sandås (2001) for Stockholm Stock Exchange.
} 


$$
\Delta \widetilde{\mathrm{p}}_{\mathrm{t}}=\sum_{\mathrm{j}} \mathrm{d}_{0, \mathrm{j}} \alpha_{\mathrm{j}}+\sum_{\mathrm{j}} \mathrm{d}_{1, \mathrm{j}} \beta_{1, \mathrm{j}} \mathrm{x}_{\mathrm{t}}+\sum_{\mathrm{j}} \mathrm{d}_{2, \mathrm{j}} \beta_{2, \mathrm{j}} \mathrm{x}_{\mathrm{t}-1}+\sum_{\mathrm{j}} \mathrm{d}_{3, j} \beta_{3, \mathrm{j}} \mathrm{x}_{\mathrm{t}-2}+\xi_{\mathrm{t}}
$$

where $\mathrm{j}=1,2$ refers to the two 30 -minute intervals before and after the news arrival, and $\mathrm{d}_{0, \mathrm{j}}$ to $d_{3, j}$ are dummy variables equaling one if the trade occurs within the related time interval, otherwise zero.

In Table 7, the first indication is that the adverse selection costs around information releases are generally lower than the normal value. This evidence suggests that order flow contains relatively little information and thus a lower risk of information asymmetry. Weak evidence of information leakage was also found in the previous literature (e.g. Ederington and Lee, 1995; Jennings, 1994; Lee, 1992).

The order processing costs around public information arrivals are also lower than normal. These estimates are consistent with the descriptive analysis in Table 3 showing that the competitiveness in liquidity provision strengthens around the disclosure time. However, order processing costs tend to increase in post-announcement trading. This evidence supports the idea that liquidity suppliers demand higher compensation for providing liquidity during the price discovery process due to a new information release.

Table 7 shows that public information arrivals produce higher order persistence costs. As shown in Goettler, Parlour and Rajan (2005), order persistence may exist even in absence of asymmetric information. My finding is also consistent with those of Table 3 and the previous literature (e.g. Greene, 2004), thus showing a higher probability of trade continuation in the same direction after news releases.

\subsection{TRANSACTION-COST COMPONENTS AND EXTREME NEWS ARRIVALS}

The final analysis of this research is to estimate the cost components around only those public 
information items that cause extreme price changes ${ }^{23}$. As discussed above, these extreme movements can be heuristically thought of as the market's response to news bulletins with a highly informative and unexpected content. I use dummy variables to recognize trades around news arrivals that engender price jumps and drops, as follows:

$$
\Delta \widetilde{\mathrm{p}}_{\mathrm{t}}=\sum_{\mathrm{k}} \mathrm{d}_{0, \mathrm{k}} \alpha_{\mathrm{k}}+\sum_{\mathrm{k}} \mathrm{d}_{1, \mathrm{k}} \beta_{1, \mathrm{k}} \mathrm{x}_{\mathrm{t}}+\sum_{\mathrm{k}} \mathrm{d}_{2, \mathrm{k}} \beta_{2, \mathrm{k}} \mathrm{x}_{\mathrm{t}-1}+\sum_{\mathrm{k}} \mathrm{d}_{3, \mathrm{k}} \beta_{3, \mathrm{k}} \mathrm{x}_{\mathrm{t}-2}+\xi_{\mathrm{t}}
$$

where $\mathrm{k}=1,2$ refers to the two 30 -minute intervals before and after the news arrival. The dummy variables $d_{0, j}$ to $d_{3, j}$ identify the occurrence of a firm-specific news arrival that causes an extreme price impact. As before, extreme negative (positive) price changes correspond to the first (last) vintile of the price return distribution covering the time period from 10 minutes before the news announcement up until the news announcement (see Table 4). To analyze good and bad news separately, I repeat the regression procedure in equation (12) for the positive and negative price impacts.

In Table 7, Panels $\mathrm{C}$ and $\mathrm{D}$ show the estimates of the cost components that are conditional on those information events that generate extreme negative (Panel C) and positive (Panel D) price impacts. Cost components around extreme movements differ from the same cost components around any information releases. Estimates both in Panels C and D suggest that adverse selection is higher before information disclosure, thus causing price disruptions. Adverse selection cost tends to decrease after the news has arrived. The findings are in line with the previous empirical findings (Brooks, 1994; Graham et al., 2003; Jennings, 1994; Krinsky and Lee, 1996) and theoretical models implying a decreasing effect of asymmetric information.

The order processing cost has an opposing pattern. The order processing cost is lower

\footnotetext{
23 I do not examine the cost components around the specific case of earnings announcements since the characteristics of that sub-sample do not guarantee an exhaustive regression analysis.
} 
than normal before extreme news arrivals and it increases afterwards. This evidence can be explained by the higher inventory costs after an information announcement implying agents' position revisions. Greene (2004) finds similar results.

Table 7 also shows that after news arrivals, the order persistence component increases (decreases) when the price drops (jumps). As depicted in Table 5, this increase is probably due to the fact that after an extreme price drop, sells are still more likely to occur than buys, but after an extreme price jump, a reversal in trade direction typically occurs.

\section{Conclusion}

My research provides a descriptive analysis of the market behavior around real-time news release arrivals. Using the Reuters alert system, I collect six months of firm-specific news for 30 highly liquid stocks quoted on the Paris Bourse. This data set represents the real-time information flow monitored by traders. Matching the news releases with the data on the intraday trading activity, I analyze the price discovery, liquidity provision, and transaction-cost components throughout the real-time information flow.

As in the previous literature on dealer markets, I find that traders in limit order book markets actually monitor and promptly react to the real-time information flow. But this is true not only for those traders who promptly process new information into prices. It is also true for limit-order traders who provide liquidity on a voluntary basis. In a competitive environment, limit-order traders normally respond to news release arrivals by supplying a significant level of liquidity. In fact, the spread is tighter and the market depth at the best quotes is thick. Market depth, trade frequency, and spread tightness are highest in the few minutes surrounding news release arrivals. However, if I analyze only public information arrivals that cause unanticipated extreme price disruption such as earnings announcements, I get a very different picture. I find 
that news bulletins with the largest price impact enlarge spreads, return volatility, and trading volume. In contrast, market depth remains in line with normal values. This finding suggests that limit-order traders provide sufficient liquidity if regarded in absolute terms, but insufficient relative to a temporary extraordinary demand for liquidity.

Second, I develop a price formation model to analyze the transaction-cost components. My results, which support earlier studies, show that the order processing cost is the largest cost component. Adverse selection and the order persistence components are smaller, but significant.

Finally, I analyze the cost components around the public information disclosure. The adverse selection cost component appears to be lower than normal. This evidence suggests that asymmetric information is only weakly relevant to the disclosure impact. Order processing costs are also smaller. This result provides further evidence on the high degree of competitiveness in liquidity provision. However, conditioning the estimation of cost components only to those public information arrivals that cause severe price impacts, I see a different picture. Extreme price movements are preceded by higher adverse selection costs and order persistence, and lower order processing costs. After extreme news arrivals, adverse selection tends to decrease and order processing cost to increase in line with the traditional view of asymmetric information models.

My study provides empirical evidence on the market quality of limit-order book markets. It shows that there is a dynamic relation between order and information flows. It also shows that a market structure based on voluntary liquidity provision is able to supply additional liquidity exactly when necessary, i.e. around information events. Even when news arrivals cause severe price disruptions, liquidity provision remains high and adverse selection and order processing costs quickly revert to their normal value. 


\section{Appendix 1: Specifications for the AR model}

The occupancy probability matrix at time $t$ of the transition matrix $P_{t}$ has the property that $\mathrm{P}_{\mathrm{t}}=\mathrm{P}^{\prime} \cdot \mathrm{P}_{\mathrm{t}-1}$. The steady state matrix $\mathrm{P}_{\mathrm{s}}$ has the property $\mathrm{P}_{\mathrm{s}}=\mathrm{P}^{\prime} \cdot \mathrm{P}_{\mathrm{s}}$ and is:

$$
\mathrm{P}_{\mathrm{s}}=\left[\begin{array}{c}
(1-\lambda) / 2 \\
\lambda \\
(1-\lambda) / 2
\end{array}\right]
$$

I calculate the steady state variance of $x_{t}$ as $\operatorname{Var}\left(x_{t}\right)=(1-\lambda)$ and the covariance and the correlation between $\mathrm{x}_{\mathrm{t}}$ and $\mathrm{x}_{\mathrm{t}-1}$ as, respectively:

$$
\begin{aligned}
& \operatorname{Cov}\left(x_{t}, x_{t-1}\right)=E\left[x_{t} x_{t-1}\right]=(1-\lambda)(2 \delta-(1-\lambda)) \\
& \operatorname{Corr}\left(x_{t}, x_{t-1}\right)=2 \delta-(1-\lambda)=\rho
\end{aligned}
$$

The covariance in (A.2) and the correlation in (A.3) can be also expressed as:

$$
\begin{aligned}
& \left.\operatorname{Cov}\left(\mathrm{x}_{\mathrm{t}}, \mathrm{x}_{\mathrm{t}-1}\right)=\sum_{\mathrm{x}_{\mathrm{t}-1}} \sum_{\mathrm{x}_{\mathrm{t}}} \mathrm{x}_{\mathrm{t}} \mathrm{x}_{\mathrm{t}-1} \mathrm{P}\left(\mathrm{x}_{\mathrm{t}} \mid \mathrm{x}_{\mathrm{t}-1}\right) \mathrm{P}\left(\mathrm{x}_{\mathrm{t}-1}\right)=(1-\lambda)(2 \delta-(1-\lambda))\right) \\
& \operatorname{Corr}\left(\mathrm{x}_{\mathrm{t}}, \mathrm{x}_{\mathrm{t}-1}\right)=\frac{\operatorname{Cov}\left(\mathrm{x}_{\mathrm{t}} \mathrm{x}_{\mathrm{t}-1}\right)}{\operatorname{Var}\left(\mathrm{x}_{\mathrm{t}}\right)}=2 \delta-(1-\lambda)=\rho
\end{aligned}
$$

Accordingly, the lagged covariance and correlation are:

$$
\begin{aligned}
& \operatorname{Cov}\left(x_{t}, x_{t-k}\right)=E\left[x_{t} x_{t-k}\right]=\sum_{x_{t-k}} \sum_{t} x_{t} x_{t-k} P\left(x_{t} \mid x_{t-k}\right) P\left(x_{t}\right)=\rho^{k}(1-\lambda) \\
& \operatorname{Corr}\left(x_{t}, x_{t-1}\right)=\frac{\operatorname{Cov}\left(x_{t} x_{t-k}\right)}{\operatorname{Var}\left(x_{t}\right)}=\rho^{k} \\
& E\left[x_{t+k} \mid x_{t}, x_{t-1}, x_{t-2}, \ldots\right]=\rho^{k} x_{t}
\end{aligned}
$$




\section{References}

Affleck-Graves, J., C. M. Callahan, and N. Chipalkatti (2002), "Earnings predictability, information asymmetry, and market liquidity", Journal of Accounting Research 40, 561-583.

Ahn, H., K. Bae, and K. Chan (2001), "Limit Orders, Depth, and Volatility: Evidence from the Stock Exchange of Hong Kong", Journal of Finance 56, 769-790.

AMF (2004), "Livre II: Emetteur et Information Financière. Autorité des marchés financiers", Paris.

Berry, T. D., and K. M. Howe (1994), "Public Information Arrival", Journal of Finance 49, 1331-1346.

Bessembinder, H., and H. M. Kaufman (1997), "A Comparison of Trade Execution Costs for NYSE and NASDAQ-listed Stocks", Journal of Financial and Quantitative Analysis 32, 287-310.

Biais, B., P. Hillion, and C. Spatt (1995), "An Empirical Analysis of the Limit Order Book and the Order Flow in the Paris Bourse", Journal of Finance 50, 1655-1689.

Brockman, P., and D. Y. Chung (1999), "Bid-Ask Spread Components in an Order-Driven Environment", Journal of Financial Research 22, 227-246.

Brooks, R. M. "Bid-Ask Spread Components around Anticipated Announcements (1994)", Journal of Financial Research 17, 375-386.

Brooks, R. M., A. Patel, and T. Su (2003), "How the Equity Market Responds to Unanticipated Events", Journal of Business 76, 109-133.

Busse, J. A., and T. C. Green (2002), "Market Efficiency in Real Time", Journal of Financial Economics 65, 415437.

Daley, L. A., J. S. Hughes, and J. D. Rayburn (1995), "The Impact of Earnings Announcements on the Permanent Price Effects of Block Trades", Journal of Accounting Research 33, 317-334.

Dann, L., D. Mayers, and R. Raab (1977), "Trading rules, large blocks and the speed of adjustment", Journal of Financial Economics 4, 3-22.

De Jong, F., T. Nijman, and A. Röell (1996), "Price Effects of Trading and Components of the Bid-Ask Spread on the Paris Bourse", Journal of Empirical Finance 3, 193-213.

Declerck, F. (2002), "Trading Costs on a Limit Order Book Market: Evidence from the Paris Bourse", Banque et Marché 57, 31-45.

Diamond, D. W., and R. E. Verrecchia (1991), "Disclosure, Liquidity, and the Cost of Capital", Journal of Finance 46, 1325-1359.

Easley, D., and M. O'Hara (1992), "Time and Process of Security Price Adjustment", Journal of Finance 47, 577605 .

Ederington, L. H., and J. H. Lee (1993), "How Markets Process Information: News Releases and Volatility", Journal of Finance 48, 1161-1191.

Ederington, L. H., and J. H. Lee (1995), "The short-term dynamics of the price adjustment to new information", Journal of Financial and Quantitative Analysis 30, 117-134.

Foucault, T., O. Kadan, and E. Kandel (2005), "Limit Order Book as a Market for Liquidity", Review of Financial Studies 18, 1171-1217.

Foucault, T., A. Röell., and P. Sandås (2003), "Market Making with Costly Monitoring: An Analysis of the SOES Controversy", Review of Financial Studies 16, 345-384.

Gajewski, J.-F. (1999), "Earnings Announcements, Asymmetric Information, Trades and Quotes", European 
Financial Management 5, 411-423.

Glosten, L., and P. Milgrom (1985), "Bid, Ask, and Transaction Prices in Specialist Market with Heterogeneously Informed Traders", Journal of Finance 14, 71-100.

Greene, T. C. (2004), "Economic News and the Impact of Trading on Bond Prices", Journal of Finance 59, 12011233.

Greene, J. T., and S. G. Watts (1996), "Price Discovery On The NYSE And The NASDAQ: The Case of Overnight and Daytime News Releases", Financial Management 25, 19-42.

Goettler, R. L., C. A. Parlour and U. Rajan (2005), "Equilibrium in Dynamic Order Book Market", Journal of Finance 60, 2149-2192.

Goldstein, M. A., and K. A. Kavajecz (2004), "Trading Strategies During Circuit Breakers and Extreme Market Movements", Journal of Financial Markets 7, 301-333.

Graham, J. R., J. Koski, and U. Loewenstein (2003), "Information Flow and Liquidity around Anticipated and Unanticipated Dividend Announcements", Journal of Business, forthcoming.

Hamao, Y. and J. Hasbrouck (1995), "Securities Trading in Absence of Dealers: Trades and Quotes on the Tokyo Stock Exchange", Review of Financial Studies 8, 849-878.

Handa, P., R. Schwartz and A. Tiwari (2003), "Quote Setting and Price Formation in an Order Driven Market", Journal of Financial Markets 6, 461-489.

Harris, L. E. (1994), "Minimum Price Variations, Discrete Bid-Ask Spread, and Quotation Sizes", Review of Financial Studies 7, 149-178.

Hasbrouck, J. (1991), "The Summary Informativeness of Stock Trades: an Econometric Analysis", Review of Financial Studies 4, 571-595.

Hausman, J., A. W. Lo, and C. MacKinlay (1992), "An Ordered Probit Analysis of Transaction Stock Prices", Journal of Financial Economics 31, 319-79.

Hollifield, B., R. Miller and P. Sandås (2004), "Empirical Analysis of Limit Order Markets", Review of Economic Studies 71, 1027-1063.

Huang, R. D., and H. R. Stoll (1997), "The Components of the Bid-Ask Spread: a General Approach", Review of Financial Studies 10, 995-1034.

Jennings, R. H. (1994), "Intraday Changes in Target Firms' Shares Price and Bid-Ask Quotes around Takeover Announcements", Journal of Financial Research 17, 255-277.

Jennings, R. H., and L. Starks (1985), "Information Content and the Speed of Stock Price Adjustment", Journal of Accounting Research 23, 336-350.

Kim, O., and R. Verrecchia (1994), "Market Liquidity and Volume around Earnings Announcements", Journal of Accounting and Economics 17, 41-67.

Krinsky, I., and J. Lee (1996), "Earnings Announcements and Components of the Bid-Ask Spread", Journal of Finance 51, 1523-1535.

Lee, C. M. C. (1992), "Earnings News and Small Trades: an Intraday Analysis", Journal of Accounting and Economics 15, 265-302.

Lee, C. M. C., B. Mucklow, and M. Ready (1993), "Spreads, Depths, and the Impact of Earnings Information: an Intraday Analysis", Review of Financial Studies 6, 345-374.

Madhavan, A., M. P. Richardson, and M. Roomans (1997), "Why Do Security Prices Change? A Transaction- 
Level Analysis of NYSE", Review of Financial Studies 10, 1035-1064.

Mitchell M. L., and J. H. Mulherin (1994), "The impact of public information on the stock market", Journal of Finance 49, 923-950.

Morse, D., and N. Ushman (1983), "The Effect of Information Announcements on Market Microstructure", Accounting Review 59, 247-258.

Parisbourse (1999), "The Paris Bourse: Organization and Procedure", Paris Bourse, Paris.

Parisbourse (2000), "Fact Book 2000", Paris Bourse, Paris.

Parlour, C. A. (1998), "Price Dynamics in Limit Order Markets", Review of Financial Studies 11, 789-816.

Patell, J. M., and M. A. Wolfson (1984), "The Intraday Speed of Adjustment of Stock Prices to Earnings and Dividend Announcements", Journal of Financial Economics 13, 223-252.

Obizhaeva, A., and J. Wang (2005), "Optimal Trading Strategy and Supply/Demand Dynamics", Working Paper, MIT.

Sandås, P. (2001), "Adverse Selection and Competitive Market Making: Empirical Evidence from a Pure Limit Order Market", Review of Financial Studies 14, 705-735.

Stoll, H. R. (1989), "Inferring the Components of the Bid Ask Spread: Theory and Empirical Tests", Journal of Finance 44, 115-134.

Venkataraman, K. (2001), "Automated Versus Floor Trading: An Analysis of Execution Costs on the Paris Bourse and New York Exchanges", Journal of Finance 56, 1445-14484.

Venkatesh, P. C., and R. Chiang (1986), "Information Asymmetry and the Dealer's Bid-Ask Spread: the Case Study of Earnings and Dividend Announcements", Journal of Finance 41, 1089-1102. 
Table 1

Description of the Sample

For each stock, the table shows company name (in "Name" column), market capitalization in millions of $€$ ("MktCap") in September 1999, price change over the sample period from April to September 1999 ("Price Change"), average daily number of trades ("Daily Trades"), average trade size in number of shares ("Volume"), average transaction price in $€$ ("Price") through the sample period, quoted spread as the difference between the ask and bid quotes ("Quoted Spread"), and percentage quoted spread (quoted spread divided by the mid-quote price) ("PQS"). The table also reports the total number of firm-specific news releases by the Reuters news alert system (in "All News" column). The total number of news items is the sum of the news items that are strictly firm-specific ("Firm News") and index-related news ("Index News"). The index-related news refers primarily to the CAC 40 index. The "Time E. A." column shows exact time stamp (day/month; hour:minute) of the Reuters news alert on the company's earnings announcements in 1999 analyzed in this study.

\begin{tabular}{|c|c|c|c|c|c|c|c|c|c|c|c|}
\hline Name & MktCap & $\begin{array}{c}\text { Price } \\
\text { Change }\end{array}$ & $\begin{array}{l}\text { Daily } \\
\text { Trades }\end{array}$ & Volume & Price & $\begin{array}{l}\text { Quoted } \\
\text { Spread }\end{array}$ & PQS & $\begin{array}{l}\text { Index } \\
\text { News }\end{array}$ & $\begin{array}{l}\text { Firm } \\
\text { News }\end{array}$ & $\begin{array}{c}\text { All } \\
\text { News }\end{array}$ & Time E. A. \\
\hline Accor & 8830 & $-6 \%$ & 564 & 144 & 232.4 & 0.424 & 0.170 & 11 & 34 & 45 & $30 / 34: 08 \mathrm{pm}$ \\
\hline Agf & 9928 & $4 \%$ & 346 & 325 & 48.2 & 0.082 & 0.166 & 6 & 71 & 77 & $16 / 92: 06 \mathrm{pm}$ \\
\hline Air Liquid & 13771 & $3 \%$ & 766 & 216 & 147.2 & 0.282 & 0.196 & 16 & 75 & 91 & $28 / 410: 58 \mathrm{am}$ \\
\hline Alcatel & 45307 & $9 \%$ & 1360 & 758 & 119.8 & 0.204 & 0.158 & 41 & 130 & 171 & 9/9 11:19 am \\
\hline Axa & 48925 & $-7 \%$ & 1199 & 945 & 120.0 & 0.178 & 0.145 & 22 & 283 & 305 & $19 / 41: 33 \mathrm{pm}$ \\
\hline BNP & 41204 & $-6 \%$ & 962 & 891 & 77.7 & 0.129 & 0.127 & 120 & 446 & 566 & $6 / 54: 12 \mathrm{pm}$ \\
\hline Canal + & 18142 & $-16 \%$ & 443 & 206 & 176.4 & 0.455 & 0.255 & 41 & 142 & 183 & $30 / 311: 43 \mathrm{am}$ \\
\hline Cap Gemini & 19521 & $-4 \%$ & 762 & 344 & 151.8 & 0.276 & 0.176 & 37 & 42 & 79 & $6 / 74: 45 \mathrm{pm}$ \\
\hline $\mathrm{Ccf}$ & 9072 & $43 \%$ & 415 & 269 & 105.5 & 0.263 & 0.251 & 35 & 83 & 118 & $15 / 94: 05 \mathrm{pm}$ \\
\hline Dexia & 6609 & $8 \%$ & 444 & 127 & 127.3 & 0.252 & 0.189 & 5 & 31 & 36 & 6/4 9:16 am \\
\hline Elf Aquit. & 42359 & $34 \%$ & 1296 & 961 & 140.8 & 0.230 & 0.149 & 125 & 552 & 677 & $13 / 8 \quad 10: 17 \mathrm{am}$ \\
\hline Eridania & 2771 & $-15 \%$ & 321 & 50 & 131.6 & 0.344 & 0.254 & 6 & 34 & 40 & 28/4 3:07 pm \\
\hline France Tel. & 134532 & $4 \%$ & 2097 & 1643 & 73.5 & 0.099 & 0.134 & 111 & 422 & 533 & $15 / 94: 30 \mathrm{pm}$ \\
\hline Danone & 17171 & $6 \%$ & 667 & 226 & 247.2 & 0.330 & 0.129 & 10 & 60 & 70 & $13 / 44: 49 \mathrm{pm}$ \\
\hline Lagardere & 6610 & $38 \%$ & 526 & 522 & 36.6 & 0.079 & 0.216 & 26 & 72 & 98 & $11 / 54: 34 \mathrm{pm}$ \\
\hline Legrand & 5985 & $11 \%$ & 294 & 45 & 209.3 & 0.575 & 0.269 & 5 & 7 & 12 & $20 / 412: 08 \mathrm{pm}$ \\
\hline LVMH & 43556 & $18 \%$ & 693 & 225 & 259.9 & 0.437 & 0.158 & 23 & 165 & 188 & 17/9 9:38 am \\
\hline Michelin & 5254 & $8 \%$ & 568 & 460 & 42.5 & 0.089 & 0.191 & 15 & 45 & 60 & 8/9 4:16 pm \\
\hline L'Oreal & 53848 & $6 \%$ & 723 & 109 & 610.3 & 1.050 & 0.163 & 7 & 20 & 27 & 8/4 9:16 am \\
\hline Peugeot & 10249 & $37 \%$ & 494 & 230 & 159.3 & 0.283 & 0.188 & 29 & 87 & 116 & 7/9 11:40 am \\
\hline Pinault & 31156 & $16 \%$ & 604 & 234 & 157.2 & 0.343 & 0.203 & 10 & 86 & 96 & $15 / 94: 10 \mathrm{pm}$ \\
\hline Promodes & 20502 & $48 \%$ & 416 & 56 & 662.5 & 1.219 & 0.176 & 21 & 123 & 144 & 4/8 4:36 pm \\
\hline Renault & 11477 & $53 \%$ & 962 & 906 & 41.3 & 0.070 & 0.183 & 57 & 213 & 270 & 2/9 4:09 pm \\
\hline Saint Gobain & 16272 & $20 \%$ & 672 & 274 & 158.6 & 0.315 & 0.187 & 16 & 31 & 47 & $22 / 74: 46 \mathrm{pm}$ \\
\hline Sodexho & 5885 & $5 \%$ & 491 & 94 & 154.8 & 0.382 & 0.236 & 10 & 9 & 19 & $7 / 411: 32 \mathrm{am}$ \\
\hline Stmicro & 44112 & $-9 \%$ & 684 & 547 & 94.5 & 0.205 & 0.211 & 75 & 68 & 143 & 19/7 9:35 am \\
\hline Thomson & 5500 & $17 \%$ & 319 & 254 & 32.2 & 0.100 & 0.305 & 19 & 78 & 97 & $15 / 91: 22 \mathrm{pm}$ \\
\hline Total Fina & 95552 & $4 \%$ & 1057 & 1166 & 120.8 & 0.179 & 0.143 & 106 & 421 & 527 & $18 / 59: 53 \mathrm{am}$ \\
\hline Usinor & 4536 & $6 \%$ & 574 & 1375 & 14.1 & 0.036 & 0.257 & 7 & 49 & 56 & 8/4 1:33 pm \\
\hline Valeo & 6341 & $-7 \%$ & 455 & 229 & 77.7 & 0.193 & 0.239 & 19 & 19 & 38 & $31 / 84: 06 \mathrm{pm}$ \\
\hline Mean & 26166 & $11 \%$ & 706 & 461 & 157.7 & 0.304 & 0.194 & 34 & 130 & 164 & \\
\hline StDev & 29361 & $18 \%$ & 388 & 424 & 145.0 & 0.262 & 0.046 & 36 & 146 & 179 & \\
\hline
\end{tabular}


Table 2

News Releases on France Telecom on April 21, 1999

The table shows a typical intraday news bulletin provided by the Reuters 2000 News Alert System. The Time and Date columns show the intraday time stamp and date of the news item arrivals. The Headline column reports the news headlines. The fourth column, "Type of News Item" indicates whether the news is index-related ("IRN") or firm-specific news ("FSN").

\begin{tabular}{cclc} 
Time & Date & Headline & $\begin{array}{c}\text { Type of } \\
\text { News Item }\end{array}$ \\
\hline 9:15 AM & 21-Apr-99 & RTRS-Paris CAC opens up, but Dow jitters dampen trade & IRN \\
10:05 AM & 21-Apr-99 & RTRS-Italy govt talking to Crediop as cell phone adviser & FSN \\
10:37 AM & 21-Apr-99 & RTRS-Mannesmann <MMNG.F> sees little risk of takeover bid & FSN \\
11:04 AM & 21-Apr-99 & RTRS-Paris CAC holds early gains in thin, jumpy trade & IRN \\
1:53 PM & 21-Apr-99 & RTRS-Spain's Airtel says intends to stay independent & FSN \\
2:13 PM & 21-Apr-99 & RTRS-Firms identified to break Internet naming monopoly & FSN \\
3:04 PM & 21-Apr-99 & RTRS-Cegetel fixed line subscribers pass one million & FSN \\
4:14 PM & 21-Apr-99 & RTRS-Paris CAC closes up but volumes thin on Dow worry & IRN \\
4:28 PM & 21-Apr-99 & RTRS-TPSA <TPSAs.WA> firm needs 6 months to build GSM net & FSN \\
4:36 PM & 21-Apr-99 & RTRS-ADR REPORT -Emerging market highlights- April 21 & FSN \\
4:59 PM & 21-Apr-99 & RTRS-BT's Valiance sees EU scrutiny of Telekom, Italia & FSN
\end{tabular}


Table 3

\section{Descriptive Analysis of the News Impacts}

The table shows the trading dynamics around public information releases. The analysis has been performed on a firm-by-firm basis. This table shows the average values across the 30 -firm sample. Measures of news impact are expressed as the percentage deviation from the nonevent period average for the same firm and time of day. I analyze the market reaction over nine 10-minute time intervals, from 30 minutes before to 60 minutes after the exact moment of the news release ("Periods"). The table reports the absolute values of the price change from the beginning and the end of the 10-minute interval in \% ("Abs. Price Change"), realized return volatility as the sum of squared price changes over the time interval in \% ("Realized Volatility"), average volume in number of shares traded over the time interval ("Volume"), market depth as the sum of the order volume pending at the best bid and ask quotes ("Depth"), average time in seconds that elapses between successive transactions ("Trade Wait"), quoted spread as the difference between the best bid and ask quotes ("Spread"), and the probability of trade continuation as the frequencies that two successive trades have the same direction ("Prob. Contin."). The column titled "No. of Obs" shows the total number of observations. Panel A shows the impact of the real-time firm-specific news flow excluding earnings announcements. In Panel B, I consider only earnings announcements. I calculate the two-tailed student's $t$-test to test significant announcement values. ** $(*)$ indicates a significance level at $1 \%(5 \%)$.

Panel A: Market Reaction to the Real-Time Firm-Specific News Flow Excluding Earnings Announcements

\begin{tabular}{ccccccccc} 
Periods & $\begin{array}{c}\text { Abs. Price } \\
\text { Change }\end{array}$ & $\begin{array}{c}\text { Realized } \\
\text { Volatility }\end{array}$ & Volume & Depth & $\begin{array}{c}\text { Trade } \\
\text { Wait }\end{array}$ & Spread & $\begin{array}{c}\text { Prob. } \\
\text { Contin. }\end{array}$ & No. of Obs \\
\hline$-30 /-20$ & 1.10 & 1.01 & 2.75 & 2.82 & -5.50 & -3.79 & 0.79 & 52724 \\
$-20 /-10$ & 2.46 & 3.62 & 3.18 & 3.16 & -6.62 & -6.06 & 0.71 & 58445 \\
$-10 / 0$ & 4.01 & 5.08 & 4.79 & 6.82 & -12.57 & -7.51 & 0.78 & 71014 \\
news/+10 & 5.64 & $14.61^{*}$ & 6.43 & $12.25^{*}$ & $-19.30^{*}$ & $-8.81^{*}$ & -0.20 & 98888 \\
$+10 /+20$ & 4.91 & 14.04 & $13.58^{*}$ & $9.73^{*}$ & $-18.95^{*}$ & -7.03 & 0.49 & 67310 \\
$+20 /+30$ & 3.99 & 5.29 & $14.71^{*}$ & 6.41 & $-13.81^{*}$ & $-9.36^{*}$ & 0.90 & 66381 \\
$+30 /+40$ & 3.95 & 1.80 & 12.28 & $10.14^{*}$ & -11.44 & -6.42 & 2.70 & 62178 \\
$+40 /+50$ & 3.24 & 2.35 & 6.96 & 5.59 & -9.28 & -4.48 & -0.84 & 60342 \\
$+50 /+60$ & 1.75 & 1.43 & 0.54 & 3.88 & -6.14 & -2.49 & 0.58 & 58884 \\
\hline
\end{tabular}

Panel B: Market Reaction to Earnings Announcements

\begin{tabular}{ccccccccc} 
Periods & $\begin{array}{c}\text { Abs. Price } \\
\text { Change }\end{array}$ & $\begin{array}{c}\text { Realized } \\
\text { Volatility }\end{array}$ & Volume & Depth & $\begin{array}{c}\text { Trade } \\
\text { Wait }\end{array}$ & Spread & $\begin{array}{c}\text { Prob. } \\
\text { Contin. }\end{array}$ & No. of Obs \\
\hline$-30 /-20$ & 2.15 & -1.39 & -3.59 & 4.26 & -5.87 & 7.20 & 0.91 & 519 \\
$-20 /-10$ & 4.15 & 3.56 & $14.65^{*}$ & 2.46 & -7.63 & 7.82 & -3.25 & 692 \\
$-10 / 0$ & $28.05^{* *}$ & $23.10^{*}$ & $20.65^{* *}$ & 6.75 & -8.46 & $11.12^{*}$ & $4.77^{*}$ & 697 \\
news/+10 & $29.38^{* *}$ & $30.15^{* *}$ & $16.77^{*}$ & $13.90^{*}$ & $-17.96^{*}$ & $16.46^{*}$ & $3.86^{*}$ & 1000 \\
$+10 /+20$ & $15.87^{*}$ & $20.72^{*}$ & 8.52 & -0.52 & $-20.97^{*}$ & $12.23^{*}$ & $3.76^{*}$ & 643 \\
$+20 /+30$ & $16.64^{*}$ & $18.66^{*}$ & 10.78 & $-22.31^{* *}$ & $-29.53^{*}$ & 6.38 & $3.52^{*}$ & 503 \\
$+30 /+40$ & $11.38^{*}$ & $20.23^{*}$ & 2.71 & -5.72 & -13.25 & 4.48 & $4.14^{*}$ & 497 \\
$+40 /+50$ & 7.47 & 12.91 & 1.69 & $-7.28^{*}$ & $-11.40^{*}$ & 3.14 & 0.24 & 492 \\
$+50 /+60$ & 2.77 & 6.86 & -1.06 & 6.87 & -9.09 & 1.45 & 1.31 & 478 \\
\hline
\end{tabular}




\section{Table 4}

\section{Descriptive Analysis of the News Impact Ranked by Price Change Size}

This table describes the news impact ranked by price change size divided in 20 quintiles (vintiles). The analysis has been performed on a firm-by-firm basis. First, for each firm I calculate transaction price changes from 10 minutes before to the exact moment of the news arrival. Then, I divide the price changes distribution into vintiles. This table reports the average values across the 30-firm sample for each vintile. Measures of news impact are the deviation values from the nonevent period average for the same firm and time of day. This table shows the transaction price change over the 10-minute intervals ("Price Change"), return volatility as the sum of squared price changes over the time interval ("Volat."), average volume in number of shares ("Volume"), market depth as the sum of the order volume pending at the best bid and ask quotes ("Depth"), average time in seconds between successive trades ("Trade Wait"), quoted spread ("Spread"), bid-to-bid (ask-to-ask) quotes change over 10-minute intervals ("Bid-to-Bid" and "Ask-to-Ask"), average order volume pending at the best bid (ask) quotes ("Depth Bid" and "Depth Ask"), the probability of trade continuation as the frequencies that two successive trades have the same direction ("Prob. Contin."), and frequency of a buy ("Prob. of Buys."). Price change, bid-to-bid and ask-toask quotes changes are expressed in basis points. All the other measures of news impact are the percentage deviation from non-announcement values. I calculate the two-tailed student's $t$-test to test significant announcement values. $* *(*)$ indicates a significance level at $1 \%(5 \%)$.

\begin{tabular}{|c|c|c|c|c|c|c|c|c|c|c|c|c|}
\hline \multicolumn{13}{|c|}{ Market impact ranked by price change (in vintiles) } \\
\hline & Price & Realized & & & Trade & & Bid-to- & Ask-to- & Depth & Depth & & Prob. \\
\hline Vintile & Change & Volat. & Volume & Depth & Wait & Spread & Bid & Ask & Bid & Ask & Contin. & Buys \\
\hline 1 & $-0.37 * *$ & $100.9 * *$ & $37.4 * *$ & $11.6^{*}$ & $-32.1 * *$ & $28.1 * *$ & $-0.29 * *$ & $-0.26 * *$ & $15.8 * *$ & $7.6^{*}$ & $8.1 * *$ & $-17.6 * *$ \\
\hline 2 & $-0.20 * *$ & $24.9 *$ & $25.4 * *$ & 0.1 & $-17.5^{*}$ & 6.8 & $-0.17^{*}$ & $-0.16^{*}$ & 1.0 & 0.7 & $7.4^{*}$ & $-15.6^{*}$ \\
\hline 3 & $-0.14^{*}$ & $37.6^{* *}$ & -2.9 & -2.5 & -12.0 & 1.4 & -0.10 & -0.10 & -2.2 & 0.9 & 1.2 & $-14.5^{*}$ \\
\hline 4 & $-0.11^{*}$ & -12.2 & 3.0 & -2.6 & -11.5 & -5.8 & -0.08 & -0.09 & 1.5 & -5.9 & $6.1 *$ & -10.4 \\
\hline 5 & -0.08 & -7.5 & $16.0^{*}$ & $7.8^{*}$ & $-15.1^{*}$ & -6.7 & -0.05 & -0.05 & 2.9 & $12.1 *$ & -0.5 & $-13.4^{*}$ \\
\hline 6 & -0.06 & $-20.7^{*}$ & 7.9 & 5.1 & -6.9 & -7.8 & -0.05 & -0.06 & $9.5^{*}$ & 3.6 & -1.7 & -6.7 \\
\hline 7 & -0.05 & $-25.2^{*}$ & -2.8 & $13.4^{*}$ & 2.5 & $-17.1^{*}$ & -0.03 & -0.03 & $16.9 * *$ & 9.5 & -0.6 & -8.9 \\
\hline 8 & -0.03 & $-14.6^{*}$ & -5.2 & $19.2 * *$ & -3.1 & $-24.1 * *$ & -0.03 & -0.03 & $11.9 *$ & $29.8 *$ & -2.0 & -10.9 \\
\hline 9 & -0.01 & -12.8 & -7.8 & 6.2 & -9.4 & $-27.1 * *$ & -0.01 & -0.02 & $9.2 *$ & 2.8 & 0.3 & -10.8 \\
\hline 10 & 0.00 & $-33.3 * *$ & -12.3 & 5.3 & -4.2 & $-23.2 * *$ & 0.00 & -0.01 & $12.7^{*}$ & -1.2 & 0.2 & -1.8 \\
\hline 11 & 0.00 & $-46.3 * *$ & $-24.7 * *$ & 1.1 & 3.7 & $-20.3 * *$ & 0.00 & -0.01 & 3.0 & -1.0 & $5.1 *$ & -4.5 \\
\hline 12 & 0.01 & $-27.4^{*}$ & 6.4 & -0.9 & -10.2 & $-21.9 * *$ & -0.01 & 0.00 & 0.2 & -5.3 & -0.1 & -1.9 \\
\hline 13 & 0.03 & $-38.0 * *$ & -11.5 & $14.7 * *$ & -6.2 & $-21.4 * *$ & 0.04 & 0.03 & $13.8^{*}$ & $16.4^{* *}$ & -0.7 & -4.7 \\
\hline 14 & 0.04 & $-23.3^{*}$ & $12.9^{*}$ & $20.3^{* *}$ & -7.0 & $-15.5^{*}$ & 0.02 & 0.02 & $16.5^{* *}$ & $28.2 * *$ & -0.9 & 1.9 \\
\hline 15 & 0.06 & -11.4 & $15.2 *$ & $20.6^{* *}$ & -5.9 & $-14.6^{*}$ & 0.04 & 0.04 & $19.1 * *$ & $22.3^{* *}$ & -0.5 & -3.4 \\
\hline 16 & 0.08 & -10.7 & 7.7 & -0.9 & -11.8 & $-12.7^{*}$ & 0.05 & 0.05 & -3.6 & 3.2 & -0.7 & 4.1 \\
\hline 17 & $0.10^{*}$ & -0.8 & -1.4 & 5.9 & -11.1 & -4.7 & 0.08 & 0.07 & 3.6 & 1.4 & -6.1 & 4.9 \\
\hline 18 & $0.14^{*}$ & $37.2 * *$ & 2.5 & 0.0 & $-21.8^{*}$ & 6.4 & 0.08 & 0.07 & -4.6 & 4.1 & 0.9 & 6.9 \\
\hline 19 & $0.19 * *$ & $48.7^{* *}$ & 7.9 & 3.1 & $-26.3 * *$ & 8.2 & $0.15^{*}$ & $0.16^{*}$ & 4.6 & 2.2 & 1.8 & $7.4^{*}$ \\
\hline 20 & $0.39 * *$ & $142.9 * *$ & $30.2 * *$ & $10.0^{*}$ & $-35.9 * *$ & $31.4^{* *}$ & $0.33 * *$ & $0.34 * *$ & $11.1^{*}$ & $8.7^{*}$ & 2.0 & $8.6^{*}$ \\
\hline
\end{tabular}


Table 5

\section{Descriptive Analysis of the News Impacts Causing Extreme Price Changes}

This table shows a 90-minute history of those news items causing the extreme price changes. The analysis was performed on a firm-by-firm basis. To find extreme price changes, I calculate price changes first for each firm from 10 minutes before to the exact moment of the news arrival. Then, I divide the price changes distribution into 20 quintiles (vintiles). Finally, I focus on the first and last vintile. The first (last) vintile represents those firmspecific news items with the most positive (negative) price impact. This table shows the average values across the 30-firm sample. Measures of news impact are the deviation values from the non-event period average for the same firm and time of day. Panel A (B) reports price drops (jumps). I divide the 90-minute history into nine 10-minute intervals ("Periods"). The table shows the log price changes over the 10-minute intervals ("Price Change"), realized return volatility as the sum of squared price changes over the time interval ("Realized Volat."), average volume in number of shares ("Volume"), market depth as the sum of order volume pending at the best bid and ask quotes ("Depth"), average time in seconds between successive trades ("Trade Wait"), quoted spread ("Spread"), logarithmic bid-to-bid (ask-to-ask) quotes change over 10-minute intervals ("Bid-to-Bid" and "Ask-to-Ask"), average order volume pending at the best bid (ask) quotes ("Depth Bid" and "Depth Ask"), probability of trade continuation as the frequencies that two successive trades have the same direction ("Prob. Contin."), and frequency of a buy ("Prob. of Buys."). Price change, bid-to-bid and ask-to-ask quotes changes are expressed in basis points. All the other measures of news impact are the percentage deviation from non-announcement values. I calculate the two-tailed student's $t$-test to test significant announcement values. $* *(*)$ indicates a significance level at $1 \%(5 \%)$.

Panel A: History of Price Drops

\begin{tabular}{|c|c|c|c|c|c|c|c|c|c|c|c|c|}
\hline Periods & $\begin{array}{c}\text { Price } \\
\text { Change }\end{array}$ & $\begin{array}{c}\text { Realized } \\
\text { Volat. }\end{array}$ & Volume & Depth & $\begin{array}{l}\text { Trade } \\
\text { Wait }\end{array}$ & Spread & $\begin{array}{c}\text { Bid-to- } \\
\text { Bid }\end{array}$ & $\begin{array}{c}\text { Ask-to- } \\
\text { Ask }\end{array}$ & $\begin{array}{c}\text { Depth } \\
\text { Bid }\end{array}$ & $\begin{array}{l}\text { Depth } \\
\text { Ask }\end{array}$ & $\begin{array}{c}\text { Prob. } \\
\text { Contin. }\end{array}$ & $\begin{array}{l}\text { Prob. } \\
\text { Buys }\end{array}$ \\
\hline$-30 /-20$ & 0.03 & $84.8 * *$ & $18.6^{*}$ & $8.2^{*}$ & $-17.7 *$ & $14.2 *$ & 0.03 & 0.04 & $9.9 *$ & 5.9 & -3.5 & 3.6 \\
\hline$-20 /-10$ & 0.08 & $91.9 * *$ & $51.0 * *$ & 4.4 & -12.0 & $15.9 *$ & 0.06 & 0.06 & $11.3 *$ & -3.3 & -3.3 & 2.3 \\
\hline$-10 / 0$ & $-0.37 * *$ & $100.9 * *$ & $37.4^{* *}$ & $11.6^{*}$ & $-32.1 * *$ & $28.1 * *$ & $-0.29 * *$ & $-0.26 * *$ & $15.8 * *$ & $7.6^{*}$ & $8.1^{*}$ & $-17.6 * *$ \\
\hline news/10 & 0.02 & $112.8 * *$ & $34.0 * *$ & -2.5 & $-18.4 *$ & $44.6^{* *}$ & 0.00 & -0.02 & $10.0^{*}$ & $-14.5 * *$ & 4.3 & $-7.5 *$ \\
\hline$+10 / 20$ & 0.01 & $81.6 * *$ & $26.3 * *$ & 0.0 & $-13.8 *$ & $21.6^{* *}$ & 0.00 & -0.03 & $8.9 *$ & $-9.3 *$ & 1.8 & -1.7 \\
\hline$+20 / 30$ & 0.00 & $61.3 * *$ & $22.6^{* *}$ & -5.0 & -11.6 & $22.3 * *$ & 0.02 & 0.01 & -3.0 & $-7.6^{*}$ & -6.3 & 2.9 \\
\hline$+30 / 40$ & 0.01 & $44.0 * *$ & $14.0 *$ & $13.0 *$ & -0.4 & $14.7 *$ & -0.01 & -0.01 & $15.0 * *$ & -4.2 & -2.2 & 1.8 \\
\hline$+40 / 50$ & -0.03 & $37.3 * *$ & 3.6 & $8.8^{*}$ & 6.2 & $16.5^{*}$ & 0.00 & -0.02 & $10.8 *$ & $8.1 *$ & 1.5 & -2.4 \\
\hline$+50 / 60$ & 0.00 & $50.9 * *$ & 8.6 & 5.1 & -10.2 & -0.3 & -0.01 & -0.01 & $14.3 *$ & -1.8 & -0.3 & -3.4 \\
\hline
\end{tabular}

Panel B: History of Price Jumps

\begin{tabular}{|c|c|c|c|c|c|c|c|c|c|c|c|c|}
\hline Periods & $\begin{array}{c}\text { Price } \\
\text { Change }\end{array}$ & $\begin{array}{c}\text { Realized } \\
\text { Volat. }\end{array}$ & Volume & Depth & $\begin{array}{l}\text { Trade } \\
\text { Wait }\end{array}$ & Spread & $\begin{array}{c}\text { Bid-to- } \\
\text { Bid }\end{array}$ & $\begin{array}{c}\text { Ask-to- } \\
\text { Ask }\end{array}$ & $\begin{array}{c}\text { Depth } \\
\text { Bid }\end{array}$ & $\begin{array}{l}\text { Depth } \\
\text { Ask }\end{array}$ & $\begin{array}{c}\text { Prob. } \\
\text { Contin. }\end{array}$ & $\begin{array}{l}\text { Prob. } \\
\text { Buys }\end{array}$ \\
\hline$-30 /-20$ & 0.04 & $27.2 * *$ & $26.2 * *$ & $8.8^{*}$ & $-29.9 * *$ & 7.2 & 0.02 & 0.02 & $8.5^{*}$ & $9.4 *$ & 2.1 & 1.4 \\
\hline$-20 /-10$ & -0.03 & $68.3 * *$ & $75.7 * *$ & -4.5 & $-26.0 * *$ & $12.8 *$ & -0.02 & -0.01 & 0.7 & $-8.7 *$ & 2.0 & -3.2 \\
\hline$-10 / 0$ & $0.39 * *$ & $142.9 * *$ & $30.2 * *$ & $10.0^{*}$ & $-35.9 * *$ & $31.4 * *$ & $0.33 * *$ & $0.34 * *$ & $11.1^{*}$ & $8.7 *$ & $4.2 *$ & $8.6^{*}$ \\
\hline news $/ 10$ & -0.04 & $131.7 * *$ & $49.0 * *$ & $8.8^{*}$ & $-31.7 * *$ & $25.6^{* *}$ & 0.00 & -0.02 & 0.4 & $17.6^{* *}$ & 0.1 & 1.8 \\
\hline$+10 / 20$ & $0.07 *$ & $182.2 * *$ & $16.2 *$ & 6.5 & $-26.6 * *$ & $21.6 * *$ & $0.05 *$ & $0.06^{*}$ & 5.9 & $7.9^{*}$ & -3.1 & 3.9 \\
\hline$+20 / 30$ & 0.01 & $68.8 * *$ & $17.2 *$ & $8.3^{*}$ & $-22.0 *$ & $18.6^{* *}$ & 0.02 & 0.01 & 0.7 & $14.9 * *$ & 1.7 & 3.8 \\
\hline$+30 / 40$ & $-0.07 *$ & $28.2 * *$ & 3.9 & $7.1 *$ & -7.3 & 0.7 & -0.03 & $-0.05^{*}$ & 6.3 & $7.9^{*}$ & 1.8 & -3.9 \\
\hline$+40 / 50$ & 0.00 & 11.0 & 11.4 & $15.2 * *$ & $-27.1 *$ & -3.6 & 0.01 & 0.01 & $18.4^{*}$ & $12.9 *$ & -0.9 & -1.0 \\
\hline$+50 / 60$ & -0.01 & 13.0 & $14.8^{*}$ & $10.0^{*}$ & -14.3 & 1.2 & 0.00 & 0.01 & $11.0^{*}$ & $9.7 *$ & 1.2 & 2.3 \\
\hline
\end{tabular}


Table 6

Order Probit Regression for the Autoregressive (AR) Model

Panel A of this table reports the average estimated coefficients from the Ordered Probit regression used to estimate the AR price formation model. The analysis has been performed on a firm-by-firm basis. This table reports the average coefficients and statistics across the 30-firm sample. The dependent variable is the trade-by-trade price change in tick size. I divide the price change sizes into nine categories: when the price drops (jumps) four ticks or less (more), when the price decreases (increases) by three ticks, two ticks, one tick, and when the price is unchanged. The explanatory variables are a constant, the trade indicator in t, t- 1 and $t-2$. On the left-hand side, the estimated coefficients of the explanatory variables are $\alpha, \beta_{1}, \beta_{2}, \beta_{3}$. In the column called "When News is Released", I estimate the AR model around news arrivals. To do this, I use the dummy variables $d_{i, j}$, for $i=0,1,2,3$ that refers to the respective coefficients, and for $\mathrm{j}=1(\mathrm{j}=2)$ if the trade occurs within 30 minutes before (after) the news arrival. In the column "When News Makes Price Drop (Jump)", I estimate the AR model around extreme negative (positive) price changes. I analyze price drops and jumps separately. Once again, I use dummy variables, $\mathrm{d}_{\mathrm{i}, \mathrm{k}} . \mathrm{i}=0,1,2,3$ refer to the respective coefficients and $\mathrm{k}=1(\mathrm{k}=2)$ detects if the trade occurs 30 minutes before (after) a news release that cause an extreme price movement. The Ordered Probit regression also provides the estimated values for the limit points $\gamma_{\mathrm{n}}$, for $\mathrm{n}=1, . .8$, those divide the nine categories of price change size. $* *(*)$ indicates a significance level from the $t$-statistic at $1 \%(5 \%)$. Panel B shows the Chi-squared statistics and related p-values for the likelihood ratio (LR) test for assessing if the coefficients before and after news arrivals are significantly different.

Panel A: Estimates from the AR model

\begin{tabular}{cc}
\multicolumn{2}{c}{ Unconditionally } \\
Coefficient & Estimate \\
\hline$\alpha$ & 0.015 \\
$\beta_{1}$ & $0.981^{* *}$ \\
$\beta_{2}$ & $-0.661 * *$ \\
$\beta_{3}$ & $-0.025 * *$
\end{tabular}

\begin{tabular}{cc}
\multicolumn{3}{c}{ When News Is Released } \\
Coefficient & Estimate \\
\hline$\alpha_{1} \mathrm{~d}_{0,1}$ & 0.013 \\
$\alpha_{2} \mathrm{~d}_{0,2}$ & 0.012 \\
$\beta_{1,1} \mathrm{~d}_{1,1}$ & $0.635^{* *}$ \\
$\beta_{1,2} \mathrm{~d}_{1,2}$ & $0.633^{* *}$ \\
$\beta_{2,1} \mathrm{~d}_{2,1}$ & $-0.449 * *$ \\
$\beta_{2,2} \mathrm{~d}_{2,2}$ & $-0.441 * *$ \\
$\beta_{3,1} \mathrm{~d}_{3,1}$ & $-0.019 * *$ \\
$\beta_{3,2} \mathrm{~d}_{3,2}$ & $-0.014 * *$
\end{tabular}

\begin{tabular}{cc}
\multicolumn{3}{c}{$\begin{array}{c}\text { When News Makes } \\
\text { Price Drop }\end{array}$} \\
\begin{tabular}{cc} 
Coefficient & Estimate \\
\hline$\alpha_{1} \mathrm{~d}_{0,1}$ & 0.001 \\
$\alpha_{2} \mathrm{~d}_{0,2}$ & 0.000 \\
$\beta_{1,1} \mathrm{~d}_{1,1}$ & $0.914 * *$ \\
$\beta_{1,2} \mathrm{~d}_{1,2}$ & $0.897 * *$ \\
$\beta_{2,1} \mathrm{~d}_{2,1}$ & $-0.600^{* *}$ \\
$\beta_{2,2} \mathrm{~d}_{2,2}$ & $-0.630 * *$ \\
$\beta_{3,1} \mathrm{~d}_{3,1}$ & $-0.032 *$ \\
$\beta_{3,2} \mathrm{~d}_{3,2}$ & $-0.036 * *$
\end{tabular}
\end{tabular}

\section{When News Makes Price Jump}

\begin{tabular}{cc} 
Coefficient & Estimate \\
\hline$\alpha_{1} \mathrm{~d}_{0,1}$ & 0.004 \\
$\alpha_{2} \mathrm{~d}_{0,2}$ & 0.003 \\
$\beta_{1,1} \mathrm{~d}_{1,1}$ & $0.942 * *$ \\
$\beta_{1,2} \mathrm{~d}_{1,2}$ & $0.928 * *$ \\
$\beta_{2,1} \mathrm{~d}_{2,1}$ & $-0.637 * *$ \\
$\beta_{2,2} \mathrm{~d}_{2,2}$ & $-0.663 * *$ \\
$\beta_{3,1} \mathrm{~d}_{3,1}$ & $-0.029 * *$ \\
$\beta_{3,2} \mathrm{~d}_{3,2}$ & $-0.012 *$
\end{tabular}

\begin{tabular}{cc}
\hline Limit Points & \\
\hline$\gamma_{1}$ & $-2.289^{* *}$ \\
$\gamma_{2}$ & $-1.984^{* *}$ \\
$\gamma_{3}$ & $-1.586^{* *}$ \\
$\gamma_{4}$ & $-1.003^{* *}$ \\
$\gamma_{5}$ & $0.925^{* *}$ \\
$\gamma_{6}$ & $1.524^{* *}$ \\
$\gamma_{7}$ & $1.921^{* *}$ \\
$\gamma_{8}$ & $2.239^{* *}$
\end{tabular}

\begin{tabular}{ll}
\hline & \\
\hline$\gamma_{1}$ & $-1.631 * *$ \\
$\gamma_{2}$ & $-1.395^{* *}$ \\
$\gamma_{3}$ & $-1.100^{* *}$ \\
$\gamma_{4}$ & $-0.698^{* *}$ \\
$\gamma_{5}$ & $0.668^{* *}$ \\
$\gamma_{6}$ & $1.071 * *$ \\
$\gamma_{7}$ & $1.362 * *$ \\
$\gamma_{8}$ & $1.607 * *$
\end{tabular}

\begin{tabular}{ll}
\hline & \\
\hline$\gamma_{1}$ & $-2.119 * *$ \\
$\gamma_{2}$ & $-1.870 * *$ \\
$\gamma_{3}$ & $-1.488^{* *}$ \\
$\gamma_{4}$ & $-0.932 * *$ \\
$\gamma_{5}$ & $0.934 * *$ \\
$\gamma_{6}$ & $1.506^{* *}$ \\
$\gamma_{7}$ & $1.856^{* *}$ \\
$\gamma_{8}$ & $2.110^{* *}$ \\
\hline
\end{tabular}

Panel B: Test if coefficients are equal before and after news arrivals

When News Makes Price Drop

When News Is Released

Chi-squared LR p-value

3.41

0.381

Chi-squared LR p-value

$12.78 \quad 0.001$

When News Makes Price Jump

Chi-squared LR p-value $10.22 \quad 0.032$ 
Table 7

The Estimates of the Cost Components from the Autoregressive (AR) Model

The table shows the estimates of the cost components that originate in the AR price formation model. The analysis has been performed on a firm-by-firm basis. This table reports the average cost components across the 30-firm sample. I analyze the cost components unconditionally and over two 30-minute time intervals, i.e. 30 minutes before and after news releases. The columns show estimates for adverse selection cost ("ASC"), order processing cost ("OPC"), and order persistence ("PERS"). Panel A shows the unconditional values of the estimated coefficients, i.e. the estimated coefficients using the entire sample. Panel B shows the estimated coefficients around real-time news arrivals. Panel C (D) shows the estimated coefficients around only those news arrivals that cause price drops (jumps). The table reports the average estimated coefficients ("Estimates"), the percentage of the cost components for the quoted spread ("In \%"), and the average monetary value of the cost components ("In $€$ ") calculated as the proportion of the quoted spread.

Panel A: Unconditional Values

\begin{tabular}{ccc} 
ESC & $\begin{array}{c}\text { Estimates } \\
\text { OPC }\end{array}$ & PERS \\
\hline 0.422 & 0.559 & 0.243
\end{tabular}

\begin{tabular}{ccc}
\multicolumn{3}{c}{ In $\%$} \\
ASC & OPC & PERS \\
\hline $34 \%$ & $46 \%$ & $20 \%$
\end{tabular}

In $€$

\begin{tabular}{ccc} 
ASC & OPC & PERS \\
\hline 0.067 & 0.089 & 0.038
\end{tabular}

Panel C: News Arrivals Causing Price Drops Estimates

\begin{tabular}{lccc} 
& ASC & OPC & PERS \\
\hline 30 min before & 0.432 & 0.482 & 0.273 \\
30 min after & 0.385 & 0.512 & 0.308
\end{tabular}

$$
\text { In } \%
$$

\begin{tabular}{lccc} 
& ASC & OPC & PERS \\
\hline 30 min before & $36 \%$ & $41 \%$ & $23 \%$ \\
30 min after & $32 \%$ & $42 \%$ & $26 \%$
\end{tabular}

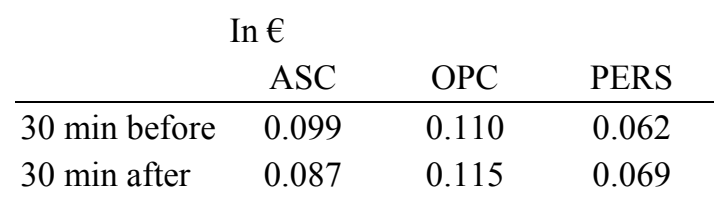

\section{Panel B: Conditional on News Arrivals}

\begin{tabular}{lccc}
\multicolumn{3}{c}{ Estimates } & \\
& ASC & OPC & PERS \\
\hline 30 min before & 0.255 & 0.380 & 0.272 \\
30 min after & 0.252 & 0.381 & 0.240
\end{tabular}

\begin{tabular}{|c|c|c|c|}
\hline \multicolumn{2}{|r|}{ In $\%$} & \multirow[b]{2}{*}{ OPC } & \multirow[b]{2}{*}{ PERS } \\
\hline & ASC & & \\
\hline $30 \mathrm{~min}$ before & $28 \%$ & $42 \%$ & $30 \%$ \\
\hline $30 \mathrm{~min}$ after & $29 \%$ & $44 \%$ & $27 \%$ \\
\hline
\end{tabular}

\begin{tabular}{|c|c|c|c|}
\hline \multicolumn{4}{|c|}{ In $€$} \\
\hline & ASC & OPC & PERS \\
\hline $30 \mathrm{~min}$ before & 0.050 & 0.075 & 0.054 \\
\hline $30 \mathrm{~min}$ after & 0.052 & 0.078 & 0.049 \\
\hline
\end{tabular}

Panel D: News Arrivals Causing Price Jumps

\begin{tabular}{lccc}
\multicolumn{3}{c}{ Estimates } & \\
& ASC & OPC & PERS \\
\hline 30 min before & 0.439 & 0.503 & 0.305 \\
30 min after & 0.327 & 0.601 & 0.191
\end{tabular}

In \%

\begin{tabular}{lccc} 
& ASC & OPC & PERS \\
\hline 30 min before & $35 \%$ & $40 \%$ & $24 \%$ \\
30 min after & $29 \%$ & $54 \%$ & $17 \%$
\end{tabular}

\begin{tabular}{lccc}
\multicolumn{2}{c}{ In $€$} & & \\
& ASC & OPC & PERS \\
\hline 30 min before & 0.079 & 0.090 & 0.055 \\
30 min after & 0.065 & 0.120 & 0.038
\end{tabular}




\section{Figure 1. Intraday Patterns of the Number of Trades and Return Volatility}

The graph illustrates the intraday patterns of two market dynamics that are the average number of trades (No. of Trades) and the return volatility (Volatility) over 30-minute time intervals. The analysis has been performed on a firm-by-firm basis. This table shows the average values across the 30 -firm sample. The volatility is 10,000 times the sample average of the sum of all the squared price changes that occur over 30 minutes. The average number of trades is the average sample of the average number of transactions exchanged over 30 minutes. The trading day at the Paris Bourse is 10:00 a.m. to 5:00 p.m.

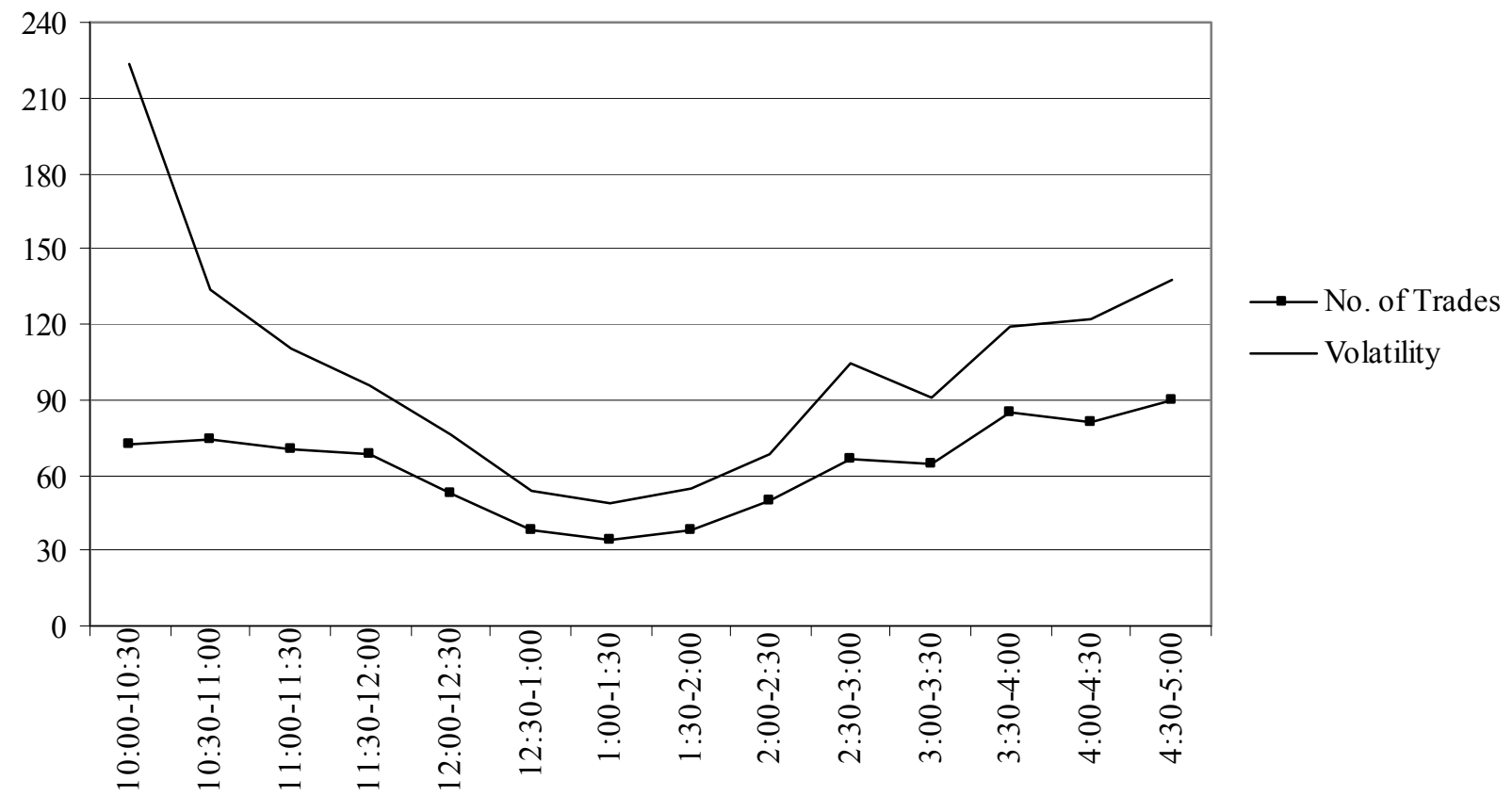

Time of Day 


\section{Figure 2. Intraday Patterns of Real-Time Information Releases}

The graph illustrates the rate of public news releases over 30-minute time intervals. I calculate the rate of public news releases as the relative frequency of the news released by the Reuters alert system. The graph shows three intraday patterns. The "Index News" curve denotes the index-related news, i.e. news that primarily refers to the CAC 40 index. The "Firm News" curve denotes the news that is strictly firm-specific. The trading day at the Paris Bourse is 10:00 a.m. to 5:00 p.m. The "Earnings News" refers to earnings announcements. The graph also shows the rates of public information releases one hour prior to the opening.

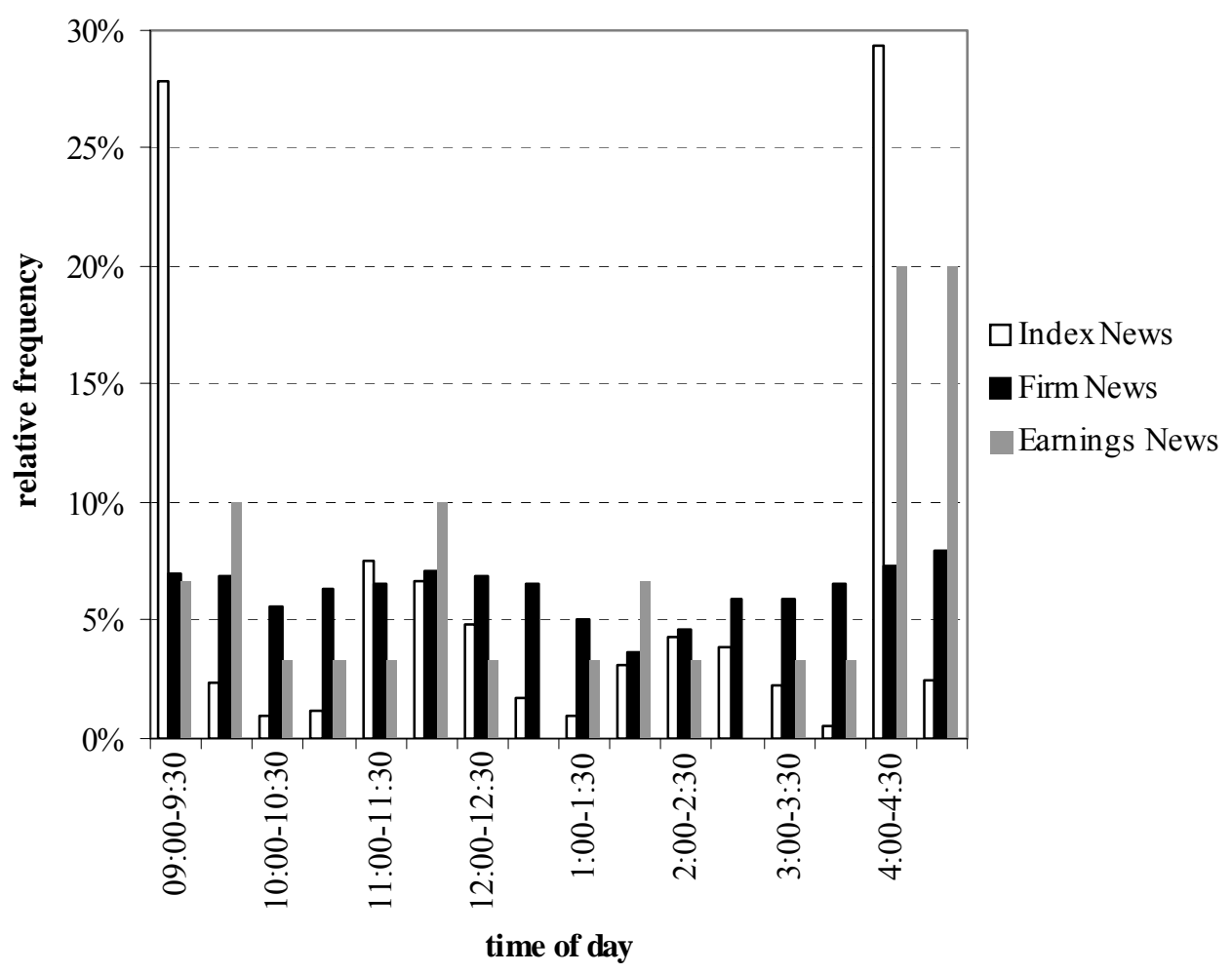




\section{Swiss National Bank Working Papers published since 2004:}

2004-1 Samuel Reynard: Financial Market Participation and the Apparent Instability of Money Demand

2004-2 Urs W. Birchler and Diana Hancock: What Does the Yield on Subordinated Bank Debt Measure?

2005-1 Hasan Bakhshi, Hashmat Khan and Barbara Rudolf: The Phillips curve under state-dependent pricing

2005-2 Andreas M. Fischer: On the Inadequacy of Newswire Reports for Empirical Research on Foreign Exchange Interventions

2006-1 Andreas M. Fischer: Measuring Income Elasticity for Swiss Money Demand: What do the Cantons say about Financial Innovation?

2006-2 Charlotte Christiansen and Angelo Ranaldo: Realized Bond-Stock Correlation: Macroeconomic Announcement Effects

2006-3 Martin Brown and Christian Zehnder: Credit Reporting, Relationship Banking, and Loan Repayment

2006-4 Hansjörg Lehmann and Michael Manz: The Exposure of Swiss Banks to Macroeconomic Shocks - an Empirical Investigation

2006-5 Katrin Assenmacher-Wesche and Stefan Gerlach: Money Growth, Output Gaps and Inflation at Low and High Frequency: Spectral Estimates for Switzerland

2006-6 Marlene Amstad and Andreas M. Fischer: Time-Varying Pass-Through from Import Prices to Consumer Prices: Evidence from an Event Study with Real-Time Data

2006-7 Samuel Reynard: Money and the Great Disinflation

2006-8 Urs W. Birchler and Matteo Facchinetti: Can bank supervisors rely on market data? A critical assessment from a Swiss perspective

2006-9 Petra Gerlach-Kristen: A Two-Pillar Phillips Curve for Switzerland

2006-10 Kevin J. Fox and Mathias Zurlinden: On Understanding Sources of Growth and Output Gaps for Switzerland

2006-11 Angelo Ranaldo: Intraday Market Dynamics Around Public Information Arrivals 
Swiss National Bank Working Papers are also available at www.snb.ch, section Publications/Research Subscriptions or individual issues can be ordered at Swiss National Bank, Fraumünsterstrasse 8, CH-8022 Zurich, fax+41 4463181 14, E-mail library@snb.ch 